\title{
Sustainability indices for energy utilization using a multi-criteria decision model
}

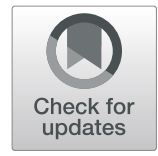

\author{
L. Suganthi
}

\begin{abstract}
Background: Energy and water availability are considered vital for a country's development. An exhaustive review of literature has been undertaken on indicators for sustainable energy development. In addition to energy and water, the resources of the country namely land availability, human capital, and nation's wealth were also found to be vital for sustainable energy development of any country. These resources have to be optimally used for sustainable energy development which is measured in terms of technical, economic, social, environmental, and institutional indices.

Methods: In this research, a multi-criteria decision model was used to measure sustainable energy development efficiency. The natural resource of the country was considered as the input criteria, while the indices were used as the output criteria. This research is unique in finding if the country's resources are being utilized in an efficient manner for sustainable development using the multi-criteria fuzzy-analytical hierarchical processing—data envelopment analysis model.

Results: From the fuzzy analytical hierarchical processing, it was found that experts were of the opinion that water availability and energy reserves were the most important parameters among the input resources, while environmental and social indices were opined to be the most important parameters among the output indices. Data envelopment analysis model was carried out using assurance region Charnes, Cooper, and Rhodes output-oriented method. The results revealed that Togo was the most efficient country with maximum sustainable energy development efficiency. Sensitivity analysis was also carried out to find which among the resources were sensitive with respect to energy sustainability for a specific country.
\end{abstract}

Conclusion: The analysis can help countries to benchmark themselves against the country lying in the efficient frontier and draft policies to improve their energy sustainability indices. Similar analysis and comparison can be done for other countries, since this research analysis was carried out only for 48 developing countries.

Keywords: Energy sustainability, Index, Sustainable development, Sustainability indices, Multi-criteria decision model

\section{Background}

Sustainable development can be defined as the development that caters to the needs of the present generation without compromising on its ability to meet the needs of the future generation [1]. With globalization and swift changeover taking place from an agricultural economy to an industrial economy [2] and then from

Correspondence: suganthi_au@yahoo.com

Department of Management Studies, College of Engineering Guindy, Anna University, Chennai 600025, India an industrial economy to green economy (https://sustainabledevelopment.un.org/index.php?page $=$ view $\&$ type $=400 \& \mathrm{n}$ $r=131 \&$ menu $=1515)$ in several fronts, the world is witnessing, on the one hand, massive consumption and large scale depletion of its natural resources while on the other hand increased environmental consciousness. Care has to be taken to ensure that such consumption does not happen at the cost of the future generation.

The rapid development in the industrial sector had tousled the planning of the resources. In both developed and developing countries, planners and policymakers are

(c) The Author(s). 2020 Open Access This article is licensed under a Creative Commons Attribution 4.0 International License, which permits use, sharing, adaptation, distribution and reproduction in any medium or format, as long as you give appropriate credit to the original author(s) and the source, provide a link to the Creative Commons licence, and indicate if changes were made. The images or other third party material in this article are included in the article's Creative Commons licence, unless indicated otherwise in a credit line to the material. If material is not included in the article's Creative Commons licence and your intended use is not permitted by statutory regulation or exceeds the permitted use, you will need to obtain permission directly from the copyright holder. To view a copy of this licence, visit http://creativecommons.org/licenses/by/4.0/ The Creative Commons Public Domain Dedication waiver (http://creativecommons.org/publicdomain/zero/1.0/) applies to the data made available in this article, unless otherwise stated in a credit line to the data. 
looking at various options for sustainable development, so that the country's resources are kept available for generations to come. Sustainable development requires judicious use of resources, technology, economic incentives, and strategic policies, at the local and national level [3].

Energy and water are considered as vital resources for a country's development. The percentage of renewable energy in the total energy scene has been declining over the years [4]. With rapid industrialization in both developed and developing countries, several energy-intensive industries have sprouted over the years [5]. Developing countries find they can very easily procure the necessary technology and the energy resources for industrialization that enabled them to quickly shift over from an agricultural economy to an industrial economy. However, it is important to note that such a transition should happen keeping sustainability in focus. In addition to energy, water is yet another resource which every country has to judiciously utilize. The development of any country is found to be directly proportional to that country's endowment of water and energy resources [6]. In addition to water and energy resources, the land is yet another vital input for energy sustainability since energy is a land-use intensive sector [7]. It is the role of policymakers to make use of the available land in an efficient manner for sustainable development. The human capital is another resource available within its national boundaries which need to be optimally utilized, since energy sustainability depends on the manpower available to support the energy activities [8]. Several researchers have established the causality relationship between national income and energy [9], and hence national income has been considered as an input criterion for energy sustainability. All of these resources have to be used in an optimal manner to meet the needs of the present generation for enhancing energy sustainability without jeopardizing the requirements of future generations.

In this paper, a framework is proposed that considers how to utilize the available resources within a country, namely energy, water, land, human capital, and national wealth in an effective manner so that it can target for higher sustainable energy development. It gives an indication of how a country can judiciously use its limited resources to achieve the desired output. While choosing the energy resources for a country, it is essential to consider the consequences of the same which will be reflected in the output indices selected for sustainable energy development. The sectors wherein course corrections need to be taken are also presented, using a multi-criteria multi-evaluation methodology. Using this framework, the policymakers can strategize their energy portfolio so that they become sustainable in the long run.

\section{Indicators for sustainable development}

Researchers have proposed various indices and metrics to find whether a country is progressing in a sustainable manner. A good framework of indicators will help policymakers to understand where the country is headed and how to provide for alternate solutions. The framework needs to present the inter-linkages and tradeoffs. Several indicators have been put forth by researchers since the Brundtland report was published in 1987 [3, 10-12].

Latin American Energy Organization (OLADE), Economic Commission for Latin America and the Caribbean (ECLAC), and the German Technical Cooperation Agency (GTZ) proposed eight indicators [13]. Millennium Development Goals' (MDG) Indicator Program proposed 60 indicators [14]. International Atomic Energy Agency (IAEA) proposed 30 indicators for Energy Indicators for Sustainable Development (EISD) $[3,15]$. Collection of data for these numerous indicators is arduous. Further deciphering and inferring information from these numerous indicators, which sometimes are in different units, becomes cumbersome. Though this wide spectrum of dashboard indicators has its own advantages, it was found that composite indicators were relatively easier to measure and compare across multiple dimensions. Some examples include the Energy for Development Index (EDI), Environmental Sustainability Index (ESI), and Environmental Performance Index (EPI).

The Energy for Development Index (EDI) [16] is a composite index that measures development in terms of energy use. The components include commercial energy consumption per capita, commercial energy share in total energy use, and percentage of the population having access to electricity. The Environmental Sustainability Index (ESI) jointly developed by Yale and Columbia universities, World Economic Forum, and European Commission Joint Research Centre is another example of a composite indicator that summarized the index from 21 indicators to measure environmental sustainability [17]. Environmental Performance Index (EPI) was also developed by the same group with 25 performance indicators. Thus, composite indicators were found to be very comprehensive and robust covering various aspects. Also, the performance of these indicators could be easily compared across dimensions, sectors, and countries. However, all these indicators calculate the status of the measure, namely environmental sustainability and do not provide a mechanism to identify how to achieve a higher level of sustainability.

\section{Composite sustainable indicators for assessing city/ region/country}

Having established the importance of composite indicators, a review of the literature was undertaken to find how composite indicators can be used to assess a city/ region/country's sustainability.

Siemens Green City Index (http://sg.siemens.com/city_of_ the_future/_docs/gci_report_summary.pdf) evaluated more 
than 120 cities around the world (27 cities in the USA and Canada, 12 cities in Germany, 30 cities in Europe, 17 cities in Latin America, 22 cities in Asia, 7 cities in Australia and New Zealand, and around 15 cities in Africa) using 30 indicators (16 quantitative and 14 qualitative) which included energy, waste, land use, water, air quality, environmental governance, and carbon dioxide $\left(\mathrm{CO}_{2}\right)$ emissions. The indices have been used without any categorization as to whether they are input or outcome parameters. It is necessary to find whether the input resources available in a country are being optimally transformed into the required output to ensure sustainability. In an indirect way, Bossel [18] has addressed this aspect. He has presented indicators for sustainable development for a state, country, and globally, in terms of an orientor, namely existence, effectiveness, freedom of action, security, adaptability, coexistence, and psychological needs. He has identified subsystem performance for each, in terms of human, support, and natural and has related it to the total system. Impact on the environment because of personal demands to meet sustainable footprint is found under coexistence dimension.

For measuring sustainability in the urban context, researchers [19-21] have used four indices, namely social, economic, community, and cultural (human). Zhang [22] has developed 22 urban sustainability indicators presented in Table 10 in Appendix which was developed in the context of urban China. The researchers have found the indicators in terms of ratio assigning weights for each. The indicators highlight to what extent urban sustainability has been achieved. As technological innovations are being witnessed across several disciplines, it is emerging as one of the important indices that have to be sustainable. In this paper, in addition to other dimensions, technical sustainability in terms of renewable energy generation and non-renewable energy substitution is measured. Dijk and Mingshun [23] using the 22 indicators developed by Zhang [22] measured urban sustainability index (USI) in four Chinese cities. Andriantiatsaholiniaina et al. [24] measured sustainable development using environmental, economic, social, political, and cultural indices.

Lee and Huang [25] based on the "3E11" structure of environment, equity (social equity), economy, and institution (politics) [26-31] proposed 51 indicators (Table 11 in Appendix). An institutional dimensional indicator has been newly proposed along with the other three indicating its growing importance. The researchers have carried a longitudinal study to measure Taipei's sustainability over a period of 11 years. Trigg et al. [32] have included a new parameter, namely quality of life, in addition to resilience and environmental performance to measure sustainability. They have compared and ranked 15 Australian cities.

On the same lines, to assess sustainability among cities, Zhou et al. [33] identified 33 indicators for lowcarbon eco-city planning in China. Kostevšek et al. [34] developed 20 indicators across energy, economy, and social aspects to assess the district heating system of Ormoz Municipality in Slovenia. Martinez [35] has used energy, economic, environmental, and social indicators (Table 12 in Appendix) to assess the energy and sustainable development in cities by taking Bogota as a case study. The indices used for measuring sustainable development focuses on energy sustainability with special reference to environmental emission. When cities become sustainable, the expectation is, it will automatically lead to a country's sustainability. However, this may not be true because of the urban-rural divide in terms of resource availability. The 17 sustainable development goals set by the United Nations are as follows: (i) No Poverty, (ii) Zero Hunger, (iii) Good Health, and Well-being; (iv) Quality Education, (v) Gender Equality, (vi) Clean Water, and Sanitation; (vii) Affordable and Clean Energy; (viii) Decent Work and Economic Growth; (ix) Industry, Innovation, and Infrastructure; (x) Reducing Inequality, (xi) Sustainable Cities, and Communities; (xii) Responsible Consumption and Production; (xiii) Climate Action, (xiv) Life Below Water, (xv) Life On Land, (xvi) Peace, Justice, and Strong Institutions; and (xvii) Partnerships for the Goals. Unless concerted efforts are taken towards achieving these goals, development will take place only in segregated pockets. Sustainable development measurement must be from a holistic perspective wherein every aspect of the economy is covered and which in consequence will lead to global sustainability.

Strunz et al [36] in their meta-analysis have clearly brought out that the resource input is a major challenge; the global community needs to address first for achieving sustainability followed by the risks associated on the sink side, namely the outcome side in terms of climate change and biodiversity loss resulting from human activity. The authors suggest that a positive framework has to be proposed rather than issuing ecological collapse warnings because such activities are found to be psychologically ineffective since they result only in fear and lack of action. Any new mechanism being ventured into should ensure there is a proper balance between the resource availability and its consumption for the ecosystem to be sustainable.

Kılkış [37] has developed a composite index, namely Sustainable Development of Energy, Water and Environment Systems (SDEWES) City Sustainability Index (Table 13 in Appendix). This is a comprehensive index drawing inferences from various research work. The index is used to benchmark cities using various themes: 


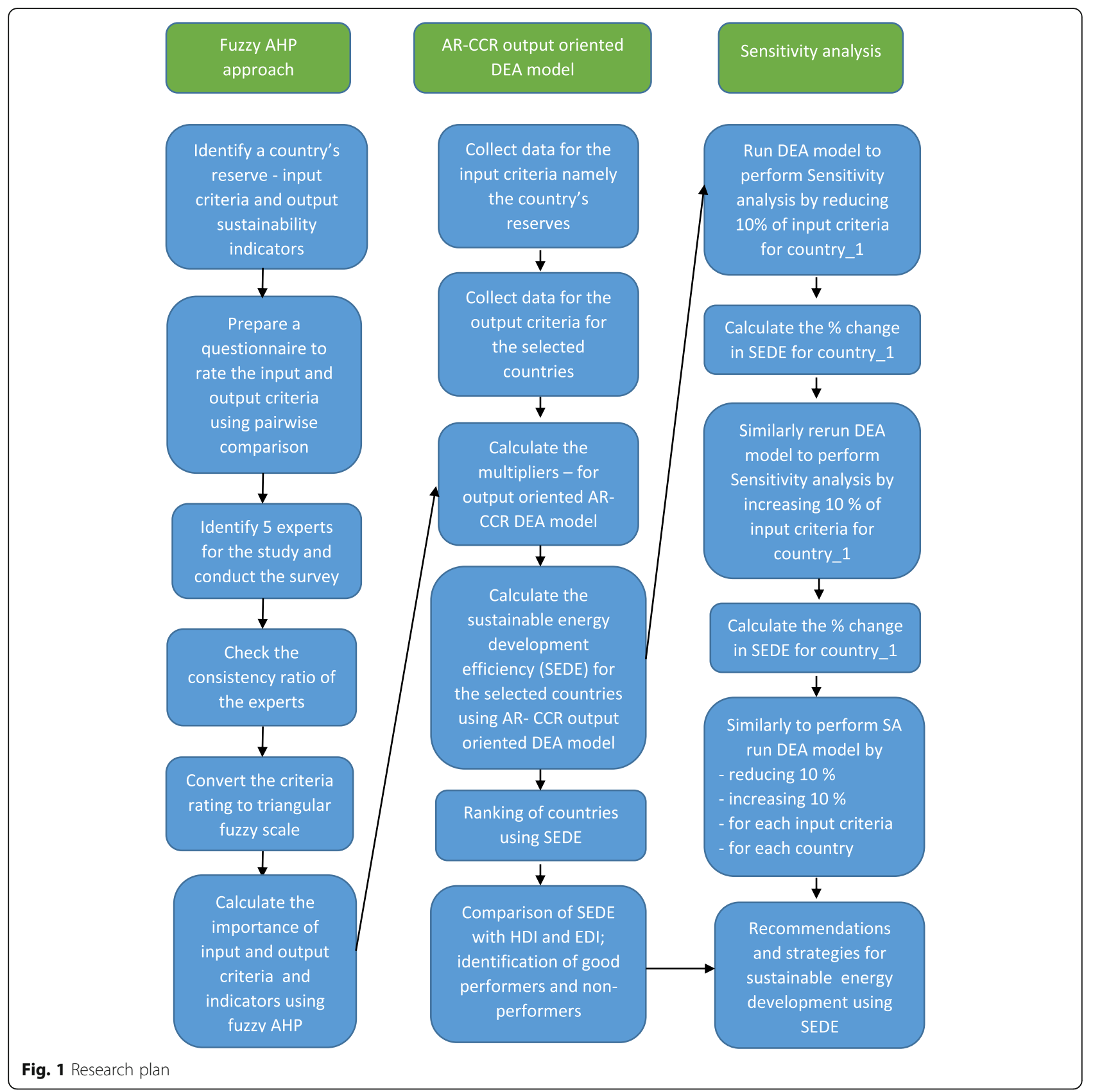

Table 1 Rating scale for rating importance of criteria

\begin{tabular}{lll}
\hline $\begin{array}{l}\text { Intensity of } \\
\text { importance }\end{array}$ & Definition & Explanation \\
\hline 1 & Equal importance & Two indicators contribute equally to sustainable development \\
2 & Weak importance of one over another & Experience and judgment slightly favor one indicator over another \\
3 & Moderate importance of one over & Experience and judgment moderately favor one indicator over another \\
4 & another & The indicator is strongly favored over another \\
5 & Extremely strong importance & $\begin{array}{l}\text { The evidence favoring one over another is of the highest possible order of } \\
\text { affirmation }\end{array}$ \\
\hline
\end{tabular}


Table 2 Triangular fuzzy (TFN) scale and its inverse TFN scale for the linguistic pairwise comparison scale

\begin{tabular}{|c|c|c|c|c|c|c|c|}
\hline \multirow[b]{2}{*}{ Just equal } & \multirow[t]{2}{*}{ Rating scale } & \multicolumn{3}{|c|}{ Triangular fuzzy numbers } & \multicolumn{3}{|c|}{ Triangular fuzzy reciprocal numbers } \\
\hline & & 1 & 1 & 1 & 1 & 1 & 1 \\
\hline Equal importance & 1 & $1 / 2$ & $1 / 1$ & $3 / 2$ & $2 / 3$ & $1 / 1$ & $2 / 1$ \\
\hline Weak importance of one over another & 2 & $1 / 1$ & $3 / 2$ & $2 / 1$ & $1 / 2$ & $2 / 3$ & $1 / 1$ \\
\hline Moderate importance of one over another & 3 & $3 / 2$ & $2 / 1$ & $5 / 2$ & $2 / 5$ & $1 / 2$ & $2 / 3$ \\
\hline Very strong importance & 4 & $2 / 1$ & $5 / 2$ & $3 / 1$ & $1 / 3$ & $2 / 5$ & $1 / 2$ \\
\hline Extremely strong importance & 5 & $5 / 2$ & $3 / 1$ & $7 / 2$ & $2 / 7$ & $1 / 3$ & $2 / 5$ \\
\hline
\end{tabular}

(i) energy consumption and climate, (ii) penetration of energy and carbon dioxide saving measures, (iii) renewable energy potential and utilization, (iv) water and environmental quality, (v) carbon dioxide emissions and industrial profile, (vi) city planning and social welfare, and (vii) research and development, innovation, and sustainability policy. It is found that the index stresses on energy, water, and emission. Though the index considers several aspects, there is a need to study sustainability from a country's perspective. Also, the resources of the country available across the nation have to be accounted for while measuring the sustainability of a country.

A data envelopment analysis (DEA) that considers inputs and outputs to measure the frontier efficiency of a decision unit was used by Yang et al. [38] to measure urban sustainability in 22 regions in Taiwan. Resources in terms of food, water, gasoline, and electricity have been considered as inputs, while gross domestic product and employment have been considered as desirable outputs, and garbage, sewage, and sulfur-oxides have been considered as undesirable outputs in the determination of urban sustainability. This research is novel in the sense that researchers have proposed a mechanism for improving urban sustainability using DEA technique by considering input resources, namely food, water, gasoline, and electricity. Taking a cue from this, it was proposed to use data envelopment analysis in this present research to identify how energy sustainability can be enhanced with the available input resources within a country. Also, the review indicated that the sustainability of a country is very much dependent on the country's inherent resources to achieve energy sustainability. Hence, in this research, energy, water, land, human capital, and national wealth have been considered as the input resources to obtain the desired sustainable energy development. In addition to social, economic, and environmental dimensions, the importance of the technical dimension was found to be

\section{INPUT CRITERIA}

OUTPUT CRITERIA

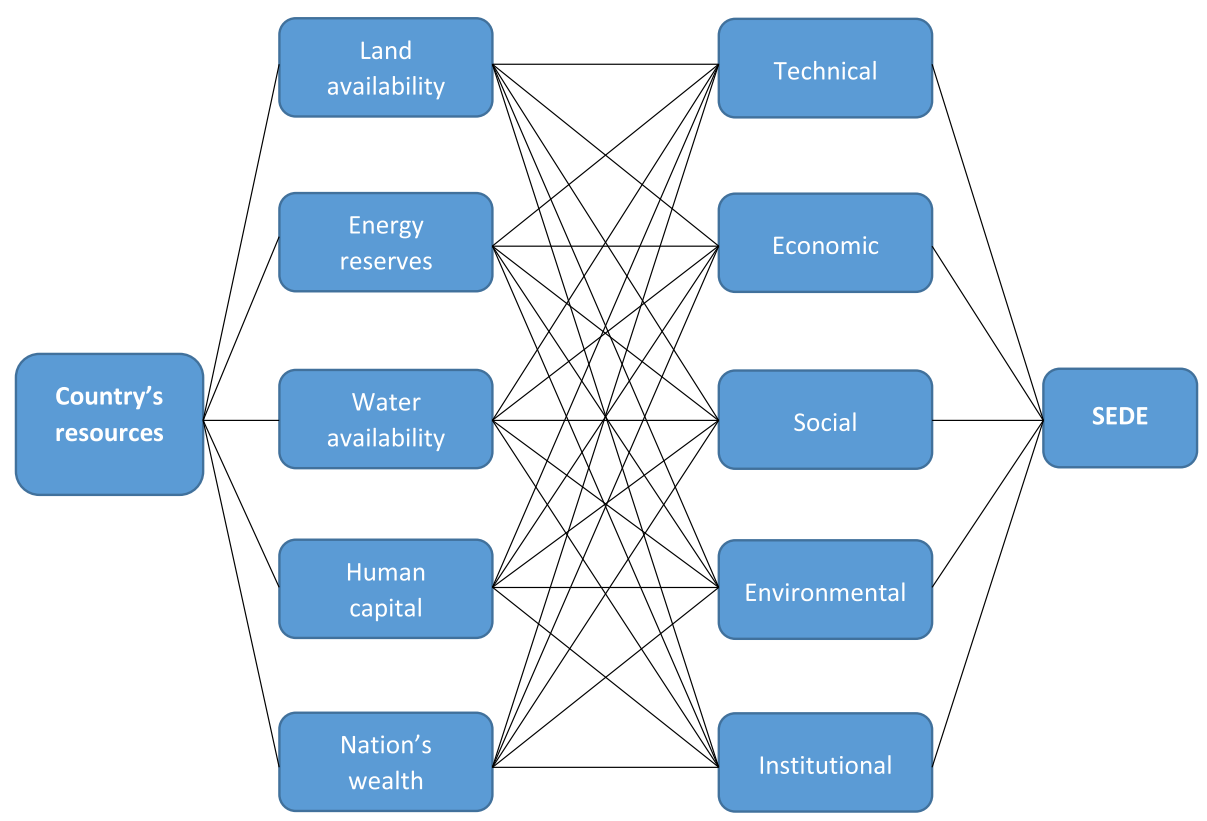

Fig. 2 Hierarchical structure of input and output criteria used in DEA 
Table 3 Country's reserves

\begin{tabular}{|c|c|c|c|c|c|c|}
\hline & Country & Land availability $\left(\mathrm{km}^{2}\right)$ & Energy reserves (toe) & Water availability $\left(\mathrm{km}^{3}\right)$ & Human capital (numbers) & National wealth (GDP per capita) \\
\hline$\overline{\mathrm{A} 1}$ & Iran & $1,745,150$ & $28,849,882,132$ & 137 & $24,639,491$ & 6247.69166 \\
\hline A2 & Argentina & $2,780,400$ & $638,822,734.5$ & 814 & $18,474,862$ & 9428.502541 \\
\hline A3 & Libya & $1,759,540$ & $6,487,981,067$ & 0.7 & $2,334,799$ & $11,631.71901$ \\
\hline A4 & Algeria & $2,381,740$ & $1,956,489,474$ & 11.67 & $10,861,377$ & 4386.038896 \\
\hline A5 & Venezuela & 912,050 & $41,166,872,931$ & 1,233 & $13,008,004$ & $13,961.94516$ \\
\hline A6 & Jordan & 89,320 & $1,495,472,421$ & 0.94 & $1,827,111$ & 3786.533481 \\
\hline A7 & Gabon & 267,670 & $335,185,309$ & 164 & 485,826 & 8449.938711 \\
\hline A8 & Ecuador & 256,370 & 1.08433E + 12 & 382 & $6,828,569$ & 4573.247084 \\
\hline A9 & Colombia & $1,141,750$ & $4,192,381,163$ & 2132 & $22,718,441$ & 6037.12981 \\
\hline A10 & Angola & $1,246,700$ & $1,415,972,331$ & 148 & $9,233,513$ & 3544.026552 \\
\hline A11 & Brazil & $8,515,770$ & $5,517,029,046$ & 8233 & $97,400,070$ & $10,538.77828$ \\
\hline A12 & Egypt & $1,001,450$ & $615,679,529$ & 57.3 & $27,333,918$ & 2524.381342 \\
\hline A13 & Costa Rica & 51,100 & $536,630.638$ & 112.4 & $2,083,466$ & 7911.7952 \\
\hline A14 & Yemen & 527,970 & $405,405,405.4$ & 2.1 & $5,229,818$ & 1249.033678 \\
\hline A15 & Uruguay & 176,220 & $310,718.5684$ & 122 & $1,695,723$ & $11,112.45603$ \\
\hline A16 & Cuba & 109,890 & $17,051,627.28$ & 38.12 & $5,204,889$ & 5550.705973 \\
\hline $\mathrm{A} 17$ & Panama & 75,420 & $87,126.4$ & 148 & $1,678,436$ & 7772.005022 \\
\hline A18 & Paraguay & 406,750 & $1,394,349.478$ & 337 & $2,907,659$ & 3996.056321 \\
\hline A19 & Tunisia & 163,610 & $57,844,521.82$ & 4.6 & $3,723,954$ & 4044.629689 \\
\hline $\mathrm{A} 20$ & Nigeria & 923,770 & $5,053,899,577$ & 950 & $47,480,739$ & 2178.898759 \\
\hline A21 & Mongolia & $1,564,120$ & $9,230,802,760$ & 34.8 & $1,151,716$ & 2533.175737 \\
\hline A22 & Peru & $1,285,220$ & $115,953,542.5$ & 1913 & $15,958,608$ & 4695.675167 \\
\hline A23 & Thailand & 513,120 & $67,897,478.86$ & 457.2 & $39,188,148$ & 4743.690472 \\
\hline A24 & Zambia & 752,610 & $2,218,992.8$ & 107.5 & $5,515,365$ & 1365.402344 \\
\hline A25 & Bolivia & $1,098,580$ & $29,027,309.27$ & 580 & $4,562,872$ & 1933.749288 \\
\hline A26 & Morocco & 446,550 & $11,698,494.35$ & 30.7 & $11,354,732$ & 2765.856154 \\
\hline A27 & Cambodia & 181,040 & $1,511,050$ & 476.1 & 7,893,797 & 752.9779185 \\
\hline A28 & Ghana & 238,540 & $92,513,764.14$ & 53.2 & $10,931,018$ & 1247.463066 \\
\hline A29 & Cameroon & 475,440 & $28,622,327.2$ & 285.5 & $8,322,260$ & 1300.84144 \\
\hline A30 & El Salvador & 21,040 & $1,031,744.897$ & 25.23 & $2,559,701$ & 2943.876855 \\
\hline A31 & Zimbabwe & 390,760 & $1,094,483,425$ & 20 & $6,671,584$ & 728.5662736 \\
\hline A32 & Philippines & 300,000 & $57,825,278.58$ & 479 & $37,641,192$ & 2010.799316 \\
\hline A33 & Botswana & 581,730 & $5,135,820,541$ & 12.24 & 833,681 & 5948.853248 \\
\hline A34 & Indonesia & $1,910,930$ & $3,101,991,363$ & 2019 & $114,924,975$ & 2970.044131 \\
\hline A35 & Benin & 114,760 & $2,022,628.078$ & 26.39 & $3,568,162$ & 763.154718 \\
\hline A36 & China & $9,562,911.25$ & $87,580,442,801$ & 2840 & $779,404,706$ & 4142.038286 \\
\hline A37 & Vietnam & $331,051.01$ & $2,728,044,533$ & 884.1 & $50,869,267$ & 1244.037152 \\
\hline A38 & Kenya & 580,370 & $3,648,940$ & 29 & $14,984,059$ & 917.0247151 \\
\hline A39 & Togo & 56,790 & $498,778.48$ & 14.7 & $2,881,260$ & 510.0840338 \\
\hline A40 & Honduras & 112,490 & $1,154,546.323$ & 95.93 & $3,227,286$ & 1900.382571 \\
\hline A41 & Sri Lanka & 65,610 & $948,802.28$ & 52.8 & $8,341,363$ & 2615.982695 \\
\hline A42 & Guatemala & 108,890 & $15,181,909.59$ & 111.3 & $5,475,328$ & 2806.986762 \\
\hline A43 & Bangladesh & 148,460 & $758,323,126.5$ & 1227 & $57,920,440$ & 725.76626 \\
\hline A44 & Nicaragua & 130,370 & $498,253.88$ & 196.6 & $2,415,768$ & 1480.376529 \\
\hline A45 & Jamaica & 10,990 & $172,903.7382$ & 9.4 & $1,344,506$ & 4777.168936 \\
\hline A46 & India & $3,287,260$ & $70,367,230,205$ & 1911 & $469,829,385$ & 1237.339786 \\
\hline A47 & Senegal & 196,710 & $394,650.48$ & 38.8 & $3,867,739$ & 1247.49782 \\
\hline A48 & Pakistan & 796,100 & $1,122,514,784$ & 246.8 & $56,949,189$ & 1045.207929 \\
\hline
\end{tabular}


Table 4 Output indices

\begin{tabular}{|c|c|c|c|c|c|c|}
\hline & Country & Technical & Economic & Social & Environmental & Institutional \\
\hline$\overline{\mathrm{A} 1}$ & Iran & 0.918 & 0.469 & 1 & 1 & 0.147 \\
\hline $\mathrm{A} 2$ & Argentina & 0.884 & 1 & 0.397 & 0.978 & 0.098 \\
\hline A3 & Libya & 0.784 & 0.79 & 0.346 & 0.877 & 0.391 \\
\hline A4 & Algeria & 0.842 & 0.365 & 0.412 & 0.993 & 0.35 \\
\hline A5 & Venezuela & 0.869 & 0.5 & 0.268 & 0.962 & 0.278 \\
\hline A6 & Jordan & 0.844 & 0.385 & 0.296 & 0.997 & 0.001 \\
\hline A7 & Gabon & 0.995 & 0.058 & 0.088 & 0.647 & 0.694 \\
\hline A8 & Ecuador & 0.967 & 0.284 & 0.155 & 0.814 & 0.219 \\
\hline A9 & Colombia & 0.897 & 0.495 & 0.077 & 0.674 & 0.284 \\
\hline A10 & Angola & 0.952 & 0.044 & 0.031 & 0.611 & 0.779 \\
\hline A11 & Brazil & 0.931 & 0.448 & 0.097 & 0.796 & 0.086 \\
\hline $\mathrm{A} 12$ & Egypt & 0.828 & 0.278 & 0.21 & 0.929 & 0.11 \\
\hline $\mathrm{A} 13$ & Costa Rica & 0.879 & 0.552 & 0.093 & 0.764 & 0.048 \\
\hline A14 & Yemen & 0.887 & 0.058 & 0.072 & 1 & 0.183 \\
\hline A15 & Uruguay & 0.594 & 0.596 & 0.198 & 0.707 & 0.032 \\
\hline A16 & Cuba & 0.809 & 0.527 & 0.138 & 0.559 & 0.042 \\
\hline A17 & Panama & 0.91 & 0.514 & 0.097 & 0.527 & 0.017 \\
\hline A18 & Paraguay & 0.962 & 0.117 & 0.077 & 0.755 & 0.142 \\
\hline A19 & Tunisia & 0.851 & 0.427 & 0.149 & 0.532 & 0.076 \\
\hline $\mathrm{A} 20$ & Nigeria & 0.992 & 0.001 & 0.008 & 0.842 & 0.192 \\
\hline A21 & Mongolia & 0.913 & 0.163 & 0.278 & 0.438 & 0.216 \\
\hline A22 & Peru & 0.989 & 0.359 & 0.061 & 0.493 & 0.086 \\
\hline A23 & Thailand & 0.875 & 0.486 & 0.076 & 0.475 & 0.053 \\
\hline A24 & Zambia & 0.918 & 0.004 & 0.013 & 0.91 & 0.082 \\
\hline A25 & Bolivia & 0.929 & 0.142 & 0.062 & 0.586 & 0.207 \\
\hline A26 & Morocco & 0.581 & 0.343 & 0.104 & 0.816 & 0.002 \\
\hline A27 & Cambodia & 0.941 & 0.008 & 0.048 & 0.71 & 0.063 \\
\hline A28 & Ghana & 0.86 & 0.041 & 0.025 & 0.743 & 0.068 \\
\hline A29 & Cameroon & 0.941 & 0.012 & 0.009 & 0.653 & 0.115 \\
\hline $\mathrm{A} 30$ & El Salvador & 0.808 & 0.151 & 0.075 & 0.641 & 0.055 \\
\hline A31 & Zimbabwe & 0.949 & 0.008 & 0.032 & 0.644 & 0.08 \\
\hline $\mathrm{A} 32$ & Philippines & 0.807 & 0.226 & 0.034 & 0.561 & 0.053 \\
\hline A33 & Botswana & 0.879 & 0.402 & 0.044 & 0.288 & 0.04 \\
\hline A34 & Indonesia & 0.895 & 0.135 & 0.079 & 0.373 & 0.158 \\
\hline A35 & Benin & 0.865 & 0.018 & 0.074 & 0.626 & 0.05 \\
\hline A36 & China & 0.843 & 0.501 & 0.1 & 0.091 & 0.083 \\
\hline A37 & Vietnam & 0.966 & 0.078 & 0.059 & 0.361 & 0.108 \\
\hline A38 & Kenya & 0.633 & 0.004 & 0.014 & 0.809 & 0.074 \\
\hline A39 & Togo & 0.591 & 0.008 & 0.016 & 0.841 & 0.074 \\
\hline $\mathrm{A} 40$ & Honduras & 0.86 & 0.103 & 0.031 & 0.455 & 0.043 \\
\hline A41 & Sri Lanka & 0.813 & 0.098 & 0.02 & 0.503 & 0.048 \\
\hline A42 & Guatemala & 0.837 & 0.093 & 0.03 & 0.462 & 0.054 \\
\hline A43 & Bangladesh & 0.839 & 0.051 & 0.029 & 0.483 & 0.075 \\
\hline A44 & Nicaragua & 0.763 & 0.068 & 0.021 & 0.5 & 0.048 \\
\hline A45 & Jamaica & 0.636 & 0.271 & 0.072 & 0.38 & 0.013 \\
\hline A46 & India & 0.832 & 0.131 & 0.048 & 0.232 & 0.066 \\
\hline A47 & Senegal & 0.77 & 0.046 & 0.021 & 0.418 & 0.037 \\
\hline A48 & Pakistan & 0.245 & 0.058 & 0.088 & 0.49 & 0.067 \\
\hline
\end{tabular}


growing, and its sustainability has to be accounted for and ensured. Similarly, the role of institutions is gaining importance in its contribution to sustainability. A unique contribution of this research is to analyze how energy sustainability can be enhanced in the five dimensions, namely economic, social, environmental, technical, and institutional using data envelopment analysis.

\section{Sustainable energy indicators}

Though there are several indicators being published to measure energy sustainability, it was found that these indicators concentrate only on certain aspects, for example, renewable energy sources [39-41] or country [42-44]. It is found that the resources available in a country have not been considered in the determination of energy sustainability. Singh et al. [10] based on their review state that an integrated framework is very much needed. The review also highlighted there exists some ambiguity and gaps in the indicators proposed. There is a need for a systematic focus in developing generic sustainable energy indicators.

The major indicators, namely OLADE, ECLAC, and GTZ [13], EDI [45], EISD [3], and multidimensional energy poverty index [14] have been extensively reviewed in several of the research papers. International Atomic Energy Agency (IAEA)/International Energy Agency (IEA) [46] under the aegis of Commission on Sustainable Development (CSD) has developed 41 indicators for sustainable energy development (ISED) and has classified them in terms of the indirect driving force, direct driving force and state (Table 14 in Appendix). This was a broad framework which indicated the driving force acts as a sort of input mechanism which results in an output. Vera et al. [47] have presented how from the original 41 ISED, the IAEA [3] have developed 30 indicators after long discourse with the United Nations Department of Economic and Social Affairs (UNDESA) and International Energy Agency (IEA). The 30 Energy Indicators for Sustainable Development (EISD) grouped the 30 indicators into three major dimensions-social (4 indicators), economic (16 indicators), and environmental (10 indicators) (Table 15 in Appendix). The indicators included both basic data as well as ratios, and hence summarizing the measures for a composite sustainable index is cumbersome. The indicators captured the consequences of energy production and utilization.

Streimikiene et al. [48] have applied the EISD tool for analyzing the trends from 1990 to 2002, setting policy goals, and for monitoring the progress towards these goals in the Baltic States. They have provided recommendations for developing sustainable energy policies. Salimov [49] has calculated the EISD economic dimension for the Azerbaijan Republic from
Table 5 Pairwise comparison of input and output criteria-expert 1

\begin{tabular}{llllllllllll}
\hline Input & $\mathrm{L}$ & $\mathrm{E}$ & $\mathrm{W}$ & $\mathrm{H}$ & $\mathrm{N}$ & Output & $\mathrm{T}$ & $\mathrm{EC}$ & $\mathrm{S}$ & $\mathrm{EN}$ & $\mathrm{I}$ \\
\hline $\mathrm{L}$ & 1 & $1 / 3$ & $1 / 2$ & 1 & $1 / 2$ & $\mathrm{~T}$ & 1 & 2 & $1 / 2$ & $1 / 2$ & 2 \\
$\mathrm{E}$ & 3 & 1 & $1 / / 2$ & $1 / 3$ & $1 / 2$ & $\mathrm{EC}$ & $1 / 2$ & 1 & $1 / 2$ & $1 / 3$ & 2 \\
$\mathrm{~W}$ & 2 & 2 & 1 & 1 & $1 / 2$ & $\mathrm{~S}$ & 2 & 2 & 1 & 2 & 2 \\
$\mathrm{H}$ & 1 & 3 & 1 & 1 & 1 & $\mathrm{EN}$ & 2 & 3 & $1 / 2$ & 1 & 2 \\
$\mathrm{~N}$ & 2 & 2 & 2 & 1 & 1 & $\mathrm{~T}$ & $1 / 2$ & $1 / 2$ & $1 / 2$ & $1 / 2$ & 1 \\
\hline
\end{tabular}

2007 to 2016 and have studied how the indicators have changed over the years and have highlighted how these indicators have given an impetus for the strategic development of the country.

To ensure all aspects of sustainability is taken care of, Bandura [50] developed 165 indices to assess sustainable development of which around 8 use some form of energy parameter. Patlitzianas et al. [51] have carried out a review on sustainable energy indicators and have proposed a framework based on their review. They stated that appropriateness, completeness, and flexibility should be the criteria for sustainable indicators selection. Indicators of security of energy supply, indicators of the competitive energy market, and indicators of environmental protection have been proposed. Jovanović et al. [52] have measured the energy system of Belgrade using sustainability energy indices from 3 dimensions, namely economy, social, and ecology (Table 16 in Appendix). Though varied aspects have been considered at the sub-indicator level, the importance and the unit of measure of each needs investigation. Mirza and Szirmai [53] have developed a composite index to calculate energy poverty, in other words, lack of sufficient energy among rural households in rural Pakistan. Vučićević et al. [54] have assessed the sustainability of energy use in residential buildings (Table 17 in Appendix) for considering economic, social, and environmental dimensions using multi-criteria analysis. This research considers energy sustainability from end-users'

Table 6 Consistency ratio of the experts for the criteria

\begin{tabular}{llll}
\hline Expert & CR input criteria & CR output criteria & Accepted \\
\hline 1 & 0.098938 & 0.059787 & Yes \\
2 & 0.075312 & 0.033563 & Yes \\
3 & 0.067906 & 0.096397 & Yes \\
4 & 0.079985 & 0.094118 & Yes \\
5 & 0.040228 & 0.036718 & Yes \\
6 & 0.098136 & 0.322252 & No \\
7 & 0.221946 & 0.071955 & No \\
\hline
\end{tabular}


Table 7 Weights given by experts for input and output criteria

\begin{tabular}{lllllllllll}
\hline Experts & $\mathrm{L}$ & $\mathrm{E}$ & $\mathrm{W}$ & $\mathrm{H}$ & $\mathrm{N}$ & $\mathrm{T}$ & $\mathrm{EC}$ & $\mathrm{S}$ & $\mathrm{EN}$ & $\mathrm{I}$ \\
\hline 1 & 0.125 & 0.155 & 0.207 & 0.238 & 0.276 & 0.181 & 0.133 & 0.317 & 0.261 & 0.107 \\
2 & 0.107 & 0.428 & 0.070 & 0.263 & 0.132 & 0.086 & 0.309 & 0.127 & 0.314 & 0.165 \\
3 & 0.072 & 0.291 & 0.459 & 0.096 & 0.083 & 0.118 & 0.083 & 0.387 & 0.342 & 0.070 \\
4 & 0.084 & 0.131 & 0.084 & 0.234 & 0.468 & 0.061 & 0.140 & 0.394 & 0.306 & 0.099 \\
5 & 0.061 & 0.240 & 0.443 & 0.159 & 0.097 & 0.358 & 0.250 & 0.090 & 0.204 & 0.099 \\
Average & 0.090 & 0.249 & 0.253 & 0.198 & 0.211 & 0.161 & 0.183 & 0.263 & 0.285 & 0.108 \\
\hline
\end{tabular}

perspective. The review highlights the following: firstly, the majority of researchers have considered sustainability in terms of three indices namely social, economic, and environmental. Secondly, the indicators were very detailed in their calculation some being numeric and some ratio, and arriving at a composite index was very challenging. Thirdly, the indicators do not link the resources of a country to energy sustainability. Any framework being proposed for determining sustainability has to ensure these concerns are addressed.

Iddrisu and Bhattacharyya [55] have formulated a composite index Sustainability Energy Development Index (SEDI) given in Table 18 in Appendix by combining five indices, namely technical, economic, social, environmental, and institutional. The SEDI has been calculated and compared across several developing countries. They have validated the index by comparing the index with HDI (Human Development Index), EDI (Energy Development Index), and EPI (Environmental Performance Index). Though energy sustainability has been calculated considering all the five indices, the link to the country's resources has not been addressed. This is vital, since for a country to become sustainable, it is necessary to check if the output delivered is in tune to the resources it is endowed with. A comprehensive composite measure for measuring sustainability index considering the country's resources is the need of the hour. This will help in comparing energy sustainability in a realistic manner across dimensions, sectors, and countries.

Using a multi-criteria Data Envelopment Analysis (DEA) methodology, it is proposed to identify how a country can progress towards sustainable development by finding a sustainable energy development efficiency (SEDE) considering the resources as the input criteria, namely land, energy, water, manpower, and national wealth and the five indices, namely technical, economic, social, environmental, and institutional as the output criteria. The results also highlight which sectors are sensitive to a certain country so that policies can be drafted keeping in mind that sector for maximizing SEDE.

\section{Methodology}

The research plan is given in Fig. 1. The research flow consists of three stages-fuzzy analytical hierarchical processing (AHP), data envelopment analysis (DEA), and sensitivity analysis.

\section{Fuzzy AHP method}

The resources, namely land availability (L), energy reserves (E), water availability (W), human capital $(\mathrm{H})$, and nation's wealth $(\mathrm{N})$ are considered as input criteria. Land availability (L) is defined as the land area of the country measured in terms of square kilometers $\left(\mathrm{km}^{2}\right)$. Energy reserves (ED) is defined as the total available energy reserves including all forms of energy in terms of tons of oil (toe). The water availability (W) is defined as the volume of water available within the country on an average measured in terms of cubic kilometers $\left(\mathrm{km}^{3}\right)$. The

Table 8 Assurance region multipliers

\begin{tabular}{llll}
\hline Min & Input criteria & Output criteria & Max \\
\hline 0.030388 & L & E & 0.493047 \\
0.390306 & L & W & 0.390306 \\
0.041215 & L & H & 0.371091 \\
0.156685 & L & N & 0.326616 \\
0.600307 & E & W & 0.79162 \\
0.752649 & E & H & 2.04353 \\
0.662445 & E & N & 5.156223 \\
0.950771 & W & H & 3.404141 \\
0.836821 & W & N & 0.836821 \\
0.48844 & H & N & 3.801633 \\
0.133186 & T & EN & 1.692353 \\
0.315021 & T & S & 0.76501 \\
0.133186 & T & EV & 2.001812 \\
0.22002 & T & I & 1.68269 \\
0.256185 & EN & S & 2.365269 \\
0.287054 & EN & EV & 1.182857 \\
1.272623 & EN & I & 1.651975 \\
0.422785 & S & EV & 1.120496 \\
0.69843 & S & I & 2.199565 \\
1.651975 & EV & & 2.104893 \\
\hline & &
\end{tabular}


Table 9 Decomposition efficiency of the countries considering their sustainability criteria

\begin{tabular}{|c|c|c|c|c|c|c|c|c|c|c|c|c|c|}
\hline & Country & Efficiency & L & $E$ & W & $\mathrm{H}$ & $\mathrm{N}$ & $\mathrm{T}$ & EC & S & EN & I & Rank \\
\hline $\bar{A} 1$ & Iran & 0.4314 & 0.3641 & 0.4456 & 0.1249 & 0.3391 & 1.0443 & 0.0279 & 0.1367 & 0.6741 & 0.1122 & 0.0491 & 8 \\
\hline A2 & Argentina & 0.2304 & 0.7963 & 0.0135 & 1.0184 & 0.3491 & 2.1637 & 0.0368 & 0.4001 & 0.3674 & 0.1507 & 0.0450 & 28 \\
\hline A3 & Libya & 0.2931 & 0.5124 & 0.1399 & 0.0009 & 0.0449 & 2.7139 & 0.0332 & 0.3214 & 0.3256 & 0.1374 & 0.1825 & 19 \\
\hline A4 & Algeria & 0.4493 & 0.7787 & 0.0474 & 0.0167 & 0.2343 & 1.1489 & 0.0401 & 0.1667 & 0.4352 & 0.1746 & 0.1834 & 6 \\
\hline A5 & Venezuela & 0.1241 & 0.3437 & 1.1485 & 2.0296 & 0.3234 & 4.2152 & 0.0477 & 0.2632 & 0.3263 & 0.1950 & 0.1679 & 37 \\
\hline A6 & Jordan & 0.6416 & 0.0414 & 0.0514 & 0.0019 & 0.0559 & 1.4079 & 0.0570 & 0.2496 & 0.4438 & 0.2489 & 0.0007 & 4 \\
\hline A7 & Gabon & 0.2523 & 0.1358 & 0.0126 & 0.3636 & 0.0163 & 3.4359 & 0.0735 & 0.0411 & 0.1443 & 0.1766 & 0.5645 & 22 \\
\hline A8 & Ecuador & 0.0212 & 0.1403 & 43.939 & 0.9133 & 0.2466 & 2.0055 & 0.0770 & 0.2171 & 0.2741 & 0.2396 & 0.1921 & 46 \\
\hline A9 & Colombia & 0.1104 & 0.6046 & 0.1644 & 4.9316 & 0.7937 & 2.5614 & 0.0691 & 0.3661 & 0.1317 & 0.1920 & 0.2410 & 39 \\
\hline $\mathrm{A} 10$ & Angola & 0.3603 & 0.6353 & 0.0534 & 0.3294 & 0.3104 & 1.4470 & 0.0302 & 0.0356 & 0.0219 & 0.1901 & 0.7222 & 15 \\
\hline A11 & Brazil & 0.0275 & 5.1903 & 0.2490 & 21.920 & 3.9168 & 5.1465 & 0.0826 & 0.3814 & 0.1910 & 0.2610 & 0.0840 & 45 \\
\hline $\mathrm{A} 12$ & Egypt & 0.3637 & 0.5374 & 0.0245 & 0.1343 & 0.9678 & 1.0854 & 0.0647 & 0.2084 & 0.3642 & 0.2682 & 0.0946 & 13 \\
\hline $\mathrm{A} 13$ & Costa Rica & 0.2404 & 0.0303 & 0.0000 & 0.2910 & 0.0815 & 3.7568 & 0.0758 & 0.4570 & 0.1781 & 0.2435 & 0.0456 & 25 \\
\hline A14 & Yemen & 0.6659 & 0.4144 & 0.0236 & 0.0072 & 0.2709 & 0.7856 & 0.1013 & 0.0636 & 0.1826 & 0.4222 & 0.2302 & 3 \\
\hline A15 & Uruguay & 0.2047 & 0.0885 & 0.0000 & 0.2678 & 0.0562 & 4.4734 & 0.0434 & 0.4183 & 0.3214 & 0.1911 & 0.0258 & 33 \\
\hline A16 & Cuba & 0.3291 & 0.0659 & 0.0008 & 0.0998 & 0.2059 & 2.6666 & 0.0706 & 0.4414 & 0.2674 & 0.1803 & 0.0404 & 16 \\
\hline A17 & Panama & 0.2089 & 0.0511 & 0.0000 & 0.4384 & 0.0751 & 4.2230 & 0.0898 & 0.4869 & 0.2126 & 0.1922 & 0.0185 & 32 \\
\hline A18 & Paraguay & 0.2249 & 0.3430 & 0.0001 & 1.2414 & 0.1618 & 2.6998 & 0.1181 & 0.1378 & 0.2098 & 0.3424 & 0.1919 & 30 \\
\hline A19 & Tunisia & 0.4381 & 0.1016 & 0.0027 & 0.0125 & 0.1526 & 2.0132 & 0.0769 & 0.3705 & 0.2991 & 0.1778 & 0.0757 & 7 \\
\hline$A 20$ & Nigeria & 0.0944 & 0.9473 & 0.3837 & 4.2557 & 3.2126 & 1.7903 & 0.3080 & 0.0009 & 0.0227 & 0.3979 & 0.2704 & 41 \\
\hline A21 & Mongolia & 0.4086 & 0.8498 & 0.3713 & 0.0826 & 0.0413 & 1.1027 & 0.0722 & 0.1237 & 0.4880 & 0.1280 & 0.1881 & 9 \\
\hline A22 & Peru & 0.0861 & 1.0319 & 0.0069 & 6.7094 & 0.8454 & 3.0207 & 0.1156 & 0.4026 & 0.1583 & 0.2129 & 0.1107 & 42 \\
\hline A23 & Thailand & 0.1564 & 0.3686 & 0.0036 & 1.4345 & 1.8572 & 2.7300 & 0.0915 & 0.4876 & 0.1764 & 0.1835 & 0.0610 & 35 \\
\hline A24 & Zambia & 0.3177 & 0.8837 & 0.0002 & 0.5514 & 0.4273 & 1.2846 & 0.3344 & 0.0037 & 0.0433 & 0.5045 & 0.1140 & 18 \\
\hline A25 & Bolivia & 0.2153 & 0.9303 & 0.0018 & 2.1456 & 0.2549 & 1.3121 & 0.1145 & 0.1680 & 0.1697 & 0.2669 & 0.2809 & 31 \\
\hline A26 & Morocco & 0.3783 & 0.3328 & 0.0006 & 0.0999 & 0.5583 & 1.6515 & 0.0630 & 0.3571 & 0.2504 & 0.3271 & 0.0024 & 10 \\
\hline A27 & Cambodia & 0.2494 & 0.2144 & 0.0001 & 2.4633 & 0.6169 & 0.7145 & 0.3458 & 0.0075 & 0.1613 & 0.3971 & 0.0883 & 23 \\
\hline A28 & Ghana & 0.3694 & 0.2938 & 0.0084 & 0.2862 & 0.8882 & 1.2309 & 0.3197 & 0.0602 & 0.0850 & 0.4204 & 0.1146 & 12 \\
\hline A29 & Cameroon & 0.2354 & 0.6090 & 0.0027 & 1.5975 & 0.7033 & 1.3350 & 0.3639 & 0.0183 & 0.0318 & 0.3843 & 0.2017 & 26 \\
\hline $\mathrm{A} 30$ & El Salvador & 0.3775 & 0.0210 & 0.0001 & 0.1098 & 0.1682 & 2.3498 & 0.1171 & 0.2101 & 0.2414 & 0.3435 & 0.0878 & 11 \\
\hline A31 & Zimbabwe & 0.4993 & 0.4944 & 0.1025 & 0.1105 & 0.5569 & 0.7386 & 0.3725 & 0.0080 & 0.1148 & 0.3847 & 0.1198 & 5 \\
\hline A32 & Philippines & 0.1444 & 0.3200 & 0.0046 & 2.2321 & 2.6492 & 1.7186 & 0.2599 & 0.2877 & 0.1001 & 0.2750 & 0.0774 & 36 \\
\hline A33 & Botswana & 0.1805 & 0.5521 & 0.3609 & 0.0508 & 0.0522 & 4.5240 & 0.2519 & 0.4553 & 0.1153 & 0.1256 & 0.0520 & 34 \\
\hline A34 & Indonesia & 0.0496 & 1.8427 & 0.2215 & 8.5050 & 7.3121 & 2.2947 & 0.2605 & 0.1553 & 0.2103 & 0.1653 & 0.2086 & 44 \\
\hline A35 & Benin & 0.7886 & 0.1351 & 0.0002 & 0.1357 & 0.2772 & 0.7199 & 0.3151 & 0.0218 & 0.2465 & 0.3471 & 0.0695 & 2 \\
\hline A36 & China & 0.0160 & 7.2030 & 4.8842 & 9.3447 & 38.734 & 2.4998 & 0.0924 & 0.5271 & 0.2434 & 0.0369 & 0.1002 & 47 \\
\hline A37 & Vietnam & 0.0985 & 0.3844 & 0.2345 & 4.4842 & 3.8970 & 1.1573 & 0.3386 & 0.1081 & 0.1891 & 0.1926 & 0.1717 & 40 \\
\hline A38 & Kenya & 0.2916 & 0.8187 & 0.0004 & 0.1787 & 1.3946 & 1.0364 & 0.2770 & 0.0045 & 0.0560 & 0.5389 & 0.1236 & 20 \\
\hline A39 & Togo & 1.0000 & 0.0789 & 0.0001 & 0.0892 & 0.2641 & 0.5678 & 0.2450 & 0.0085 & 0.0606 & 0.5689 & 0.1171 & 1 \\
\hline A40 & Honduras & 0.3246 & 0.1528 & 0.0001 & 0.5694 & 0.2893 & 2.0688 & 0.3527 & 0.1670 & 0.1163 & 0.2840 & 0.0800 & 17 \\
\hline A41 & Sri Lanka & 0.2428 & 0.0918 & 0.0001 & 0.3229 & 0.7704 & 2.9339 & 0.3436 & 0.1637 & 0.0773 & 0.3235 & 0.0920 & 24 \\
\hline A42 & Guatemala & 0.2285 & 0.1486 & 0.0015 & 0.6636 & 0.4931 & 3.0697 & 0.3449 & 0.1515 & 0.1130 & 0.2897 & 0.1009 & 29 \\
\hline A43 & Bangladesh & 0.0721 & 0.2065 & 0.0781 & 7.4571 & 5.3167 & 0.8090 & 0.3524 & 0.0847 & 0.1114 & 0.3087 & 0.1428 & 43 \\
\hline A44 & Nicaragua & 0.2848 & 0.1961 & 0.0001 & 1.2917 & 0.2397 & 1.7839 & 0.3464 & 0.1220 & 0.0872 & 0.3455 & 0.0988 & 21 \\
\hline
\end{tabular}


Table 9 Decomposition efficiency of the countries considering their sustainability criteria (Continued)

\begin{tabular}{llllllllllllll}
\hline & Country & Efficiency & L & E & W & H & N & T & EC & S & EN & I & Rank \\
\hline A45 & Jamaica & 0.2341 & 0.0118 & 0.0000 & 0.0442 & 0.0955 & 4.1201 & 0.0996 & 0.4075 & 0.2504 & 0.2200 & 0.0224 & 27 \\
A46 & India & 0.0151 & 4.4608 & 7.0698 & 11.328 & 42.065 & 1.3453 & 0.3408 & 0.2121 & 0.1798 & 0.1446 & 0.1226 & 48 \\
A47 & Senegal & 0.3628 & 0.3345 & 0.0000 & 0.2882 & 0.4340 & 1.6998 & 0.3953 & 0.0933 & 0.0986 & 0.3266 & 0.0861 & 14 \\
A48 & Pakistan & 0.1178 & 1.0313 & 0.1077 & 1.3966 & 4.8674 & 1.0848 & 0.0462 & 0.1050 & 0.3683 & 0.3414 & 0.1391 & 38 \\
\hline
\end{tabular}

human capital $(\mathrm{H})$ is defined as the manpower available for employment (numbers). For this research purpose, the nation's wealth is defined to be the gross domestic product available per person (GDP per capita). As various units of measure have been used among the input criteria, normalization was carried out before performing DEA. The framework of this research proposes that the available resources have to be utilized optimally to achieve sustainable energy development. However, sustainable energy development is defined to have multiple criteria and maximizing each of these criteria is expected to result in overall maximum sustainable energy development.

Based on the review of literature, five indices have been considered as the output criteria, namely technical (T), economic (EC), social (S), environmental (EN), and institutional (I) that has to be maximized for achieving sustainable energy development. Since there are multiple outputs that have to be simultaneously maximized with the available input resources, a multi-criteria decision model, namely data envelopment analysis is chosen for this research. The values of these five output criteria for various countries calculated by Iddrisu and Bhattacharyya [55] are used in this research.

To obtain a higher degree of precision, fuzzy AHP has been used to determine the relative weights of the five input and five output criteria based on intuitionistic judgment and to develop a hierarchical multi-criteria decision-making (MCDM) model.

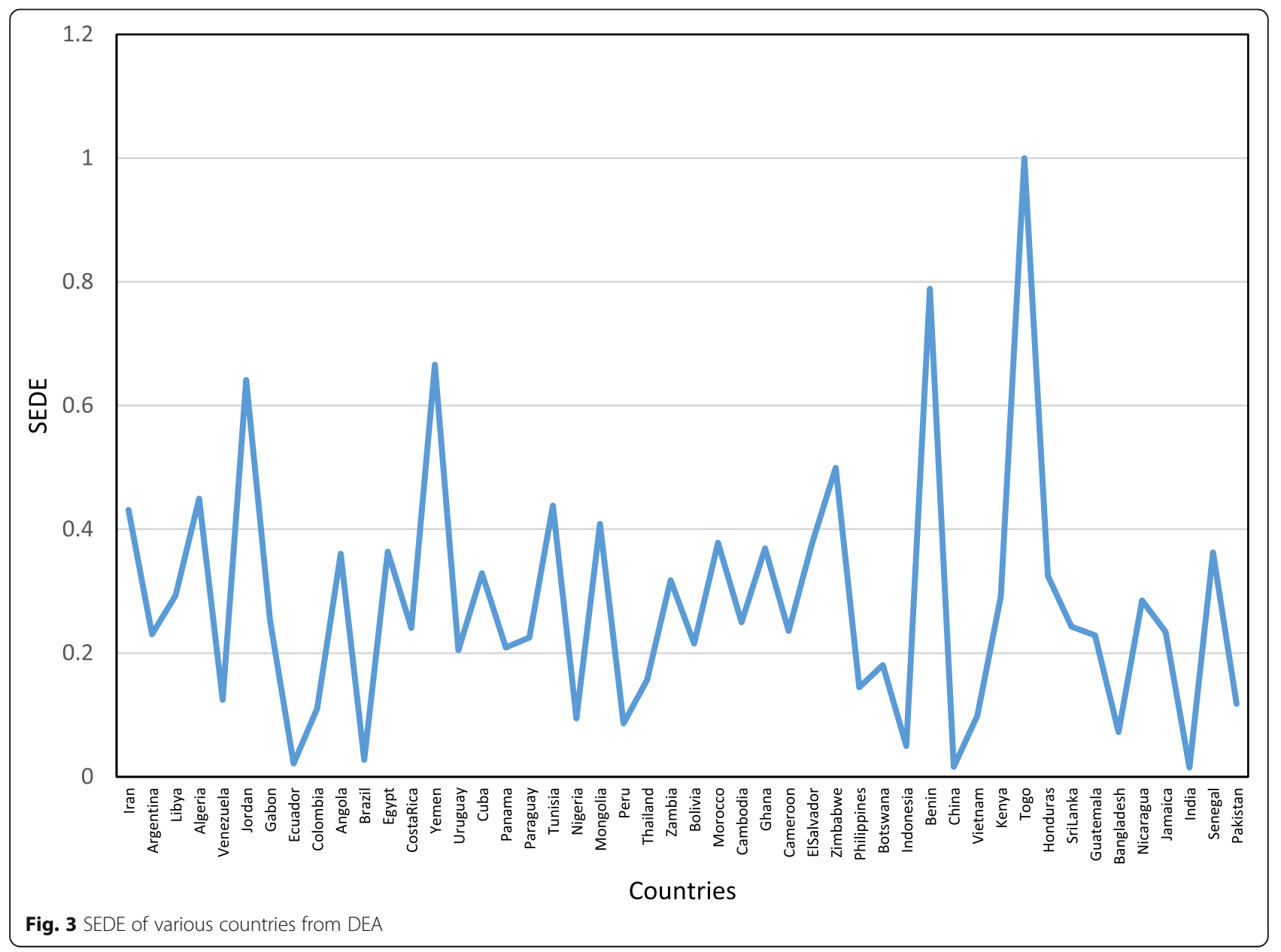


A questionnaire for pairwise comparison among the input and output criteria was designed for distributing to the experts. The criteria weights are based on the expert's opinion, and hence the selection of the experts has to be judiciously done. The number of experts chosen for the study was based on the expert's accessibility and availability. Research does not mention the number of experts essential to conduct AHP [56]. It is very important to select the expert with the right competence so that there is unanimity in the decision process. The research also highlighted that the significance of expert competence is inversely proportional to the group size whenever there is group decision-making [57]. The extant literature confirmed that smaller expert size will help in getting an effective response since there will be a concerted effort.

As the decision process involved an evaluation of criteria dealing with sustainable development, seven experts were chosen for the study. The expert group comprised of two government officials, two industrialists, two consultants, and one academician. All the experts chosen for this study were of Indian origin. The first expert who was a government official had a doctorate in energy management with 18 years of government service. He belonged to the Indian administrative service and has been holding various administrative positions in state-owned electricity and pollution control organizations. The second expertwho is again a government official with 22 years of government service-had done his graduation in electrical engineering and has been holding various positions in the state-owned electricity board. The third expert was a science graduate with 18 years of industrial experience working in a renewable energy organization handling solar and wind energy projects. The fourth expert had done mechanical engineering and business administration and is working in an energy organization. He is involved in sanctioning and commissioning of energy projects and has 21 years of industrial experience. The fifth expert was a consultant with 15 years of experience as a consultant. His job profile included preparing feasibility reports and drafting of project proposals in the energy sector for availing bank loans. The sixth expert was a consultant in a quasi-government organization that acts as a facilitator between industrial partners and financial

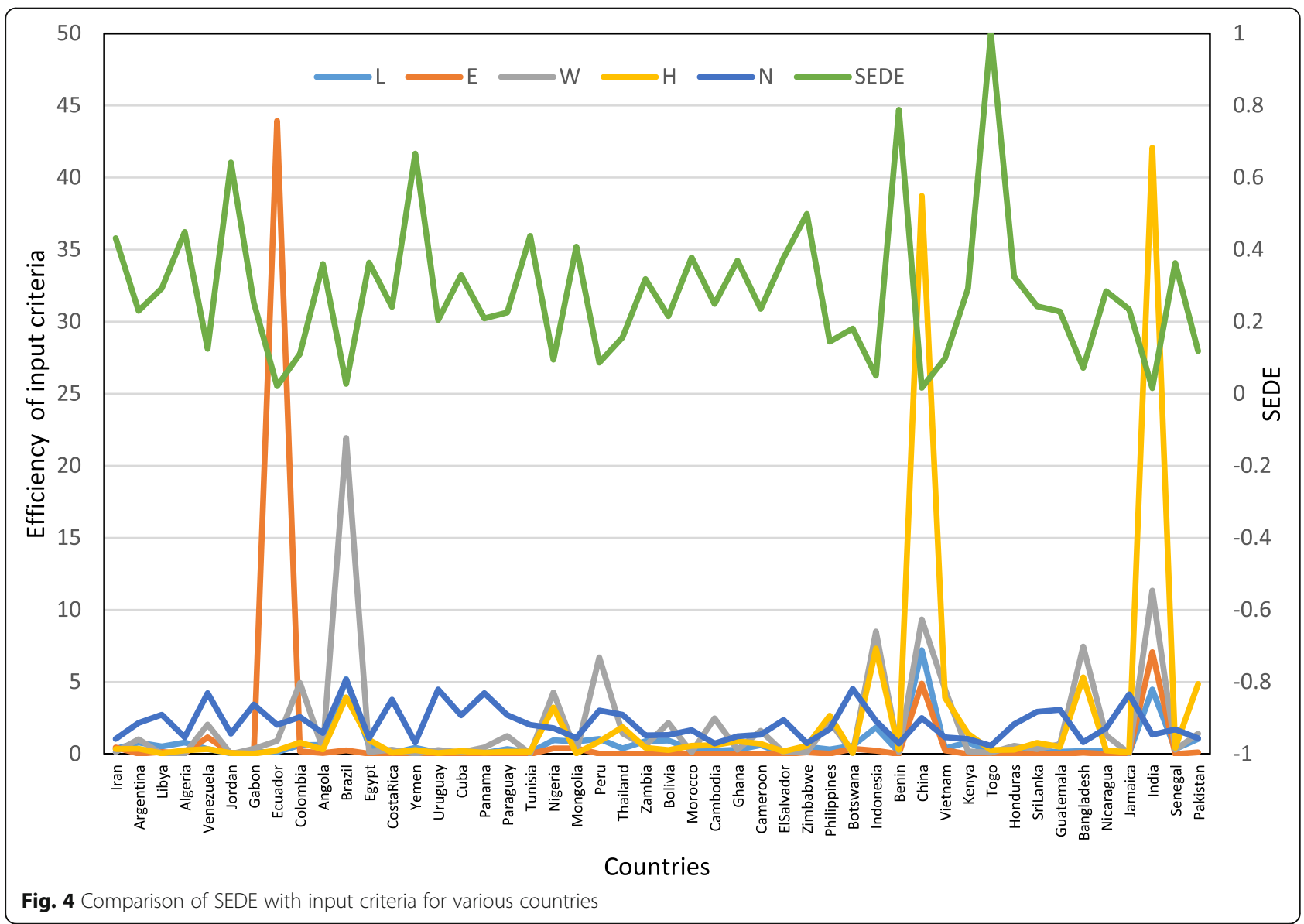


institutions. He was instrumental in scrutinizing the project proposals and facilitated the smooth transfer of bank loans to the industrial partners from the financial institutions. He has a total experience of 20 years as consultant handling projects in various disciplines including energy. The seventh expert was an academician with 27 years of experience. He had completed his graduation in mechanical engineering, postgraduation in thermal sciences, and a doctoral degree in energy systems. His area of expertise is energy management with special reference to renewable energy. The right choice of experts was very important for this study. It was found that the experts' years of work experience ranged from 15 to 27 years. The area of their expertise included energy and energy-related disciplines.

The experts were requested to do a pairwise comparison of the input and output criteria and rate the importance of using a rating scale (Table 1). Consistency index and consistency ratio (CR) were calculated for each expert [58,59]. The rating of an expert was accepted if $\mathrm{CR} \leq 0.10$. The ratings given by the experts were then converted to fuzzy weights using triangular fuzzy scale (TFN) (Table 2) [60]. The weight vectors were determined and normalized to obtain relative weights $[58,59]$.

\section{Sustainable energy development efficiency using DEA}

Data envelopment analysis (DEA) is a multi-criteria multi-evaluation non-parametric method used to measure the relative efficiency of a set of alternatives considering input and output criteria. The fuzzy AHP weights were used as priority weights for the criteria in DEA analysis. Figure 2 shows the hierarchical structure of the DEA model. In the DEA analysis, CCR model, namely Charnes, Cooper, and Rhodes [61] model was adopted to find the relative efficiency ranging from 0 to 1 . This model considered production components as constant return-to-scale. An assurance region Charnes, Cooper, and Rhodes (AR-CCR) output-oriented model was selected to avoid null output in the analysis. The relative efficiency was calculated using a country's resources as input criteria, the five indices, namely technical, economic, social, environmental, and institutional as output criteria to evaluate the sustainable energy development efficiency among the developing countries. Forty-eight countries have been chosen for the study. The input values (country's natural reserves) were collected from various sources. The energy reserves data for the 48 countries were collected from several websites ([62], http://www.economywatch.com/economic-statistics/) for each of the energy sources, namely coal, oil, fuelwood,

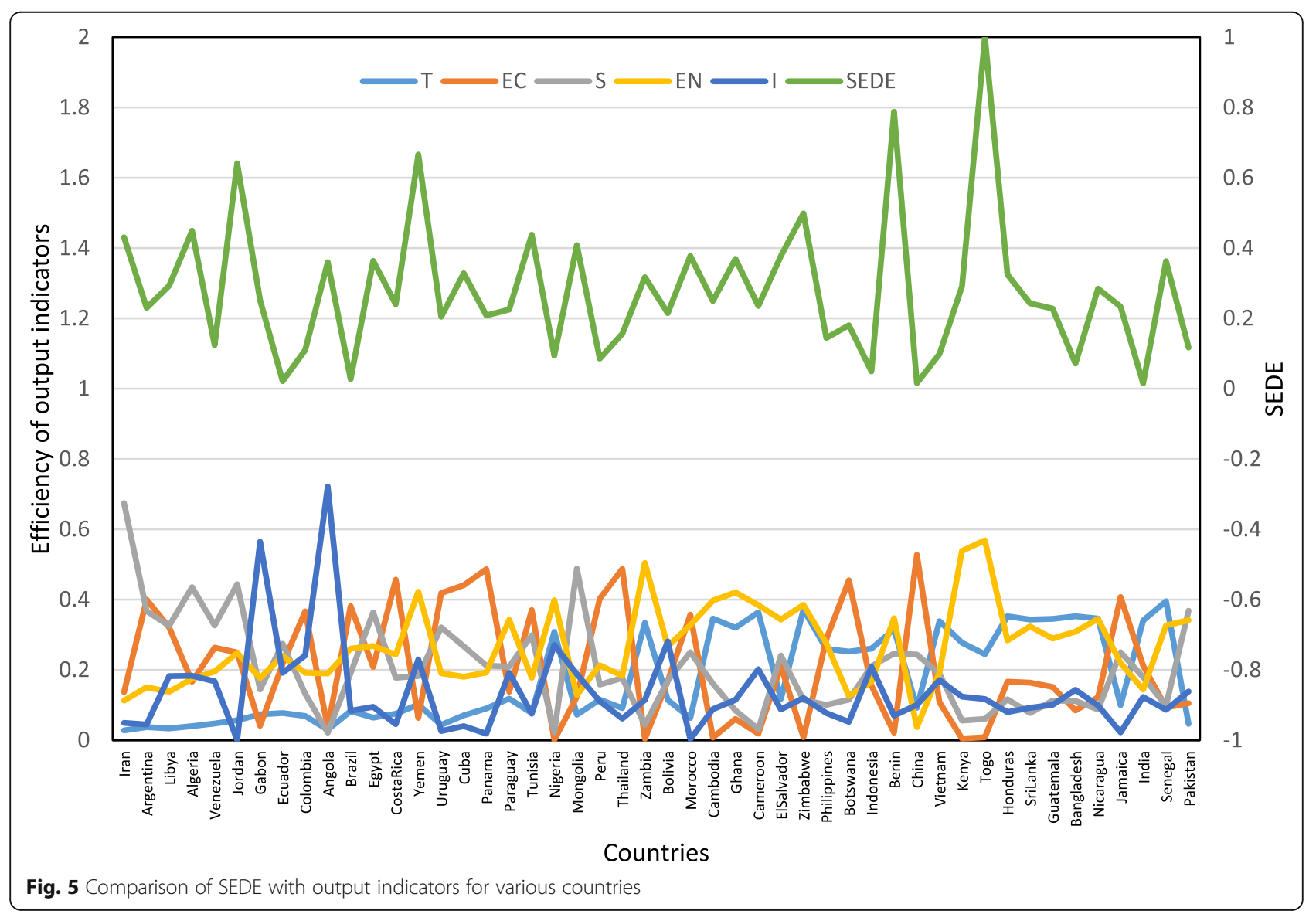


bagasse, natural gas, nuclear, and wind. The total energy reserves were then calculated in tons of oil equivalent (toe). The land availability (unit $\mathrm{km}^{2}$ ), human capital (employable labor in numbers), and national wealth (GDP per capita constant US dollar) was collected from World Bank data [4]. The water in terms of renewable water resources $\left(\right.$ unit $\mathrm{km}^{3}$ ) for the 48 countries was collected [63]. The data used as input is given in Table 3.

As already highlighted in the literature review, the researcher has found that the triple bottom approach with only economic, environmental, and social criteria for ascertaining the sustainability is insufficient. Considering this, it is found that sustainability needs to be assessed from all perspectives. For energy sustainability from the technical perspective, the proportion of renewable energy utilization as compared to primary energy should be on the increase. Also, the locally available energy should not be exploited to a large extent. In all cases, for technical energy sustainability, the conversion efficiency should be maximum. From the economic perspective, it is essential to ensure the energy intensity declines, the per capita energy consumption is efficient, and the energy being used is productively utilized by its consumers. To ensure environmental sustainability, it is essential that the emissions from the primary energy sources are kept at the base minimum. From the social perspective, the energy consumed is clean and equality is maintained across all consumers. For the institution to achieve energy sustainability, it is prerogative to ensure that energy is produced using indigenous production process for achieving self-sufficiency. Considering these as the goals for achieving energy sustainability, they are treated as the output criteria. It was found from a review that the indices used by Iddrisu and Bhattacharyya [55] given in Table 18 in Appendix were appropriate for this research, and hence it was used as the output criteria. The values of the output criteria are given in Table 4 .

The analysis yielded an efficient frontier which was considered to be the best among the alternatives for a given set of criteria. The results helped in identifying hidden relationships existing among the multiple criteria taken together. DEA is a versatile tool since it is capable of handling multiple inputs and outputs and secondly presents the frontier alternative considering both the

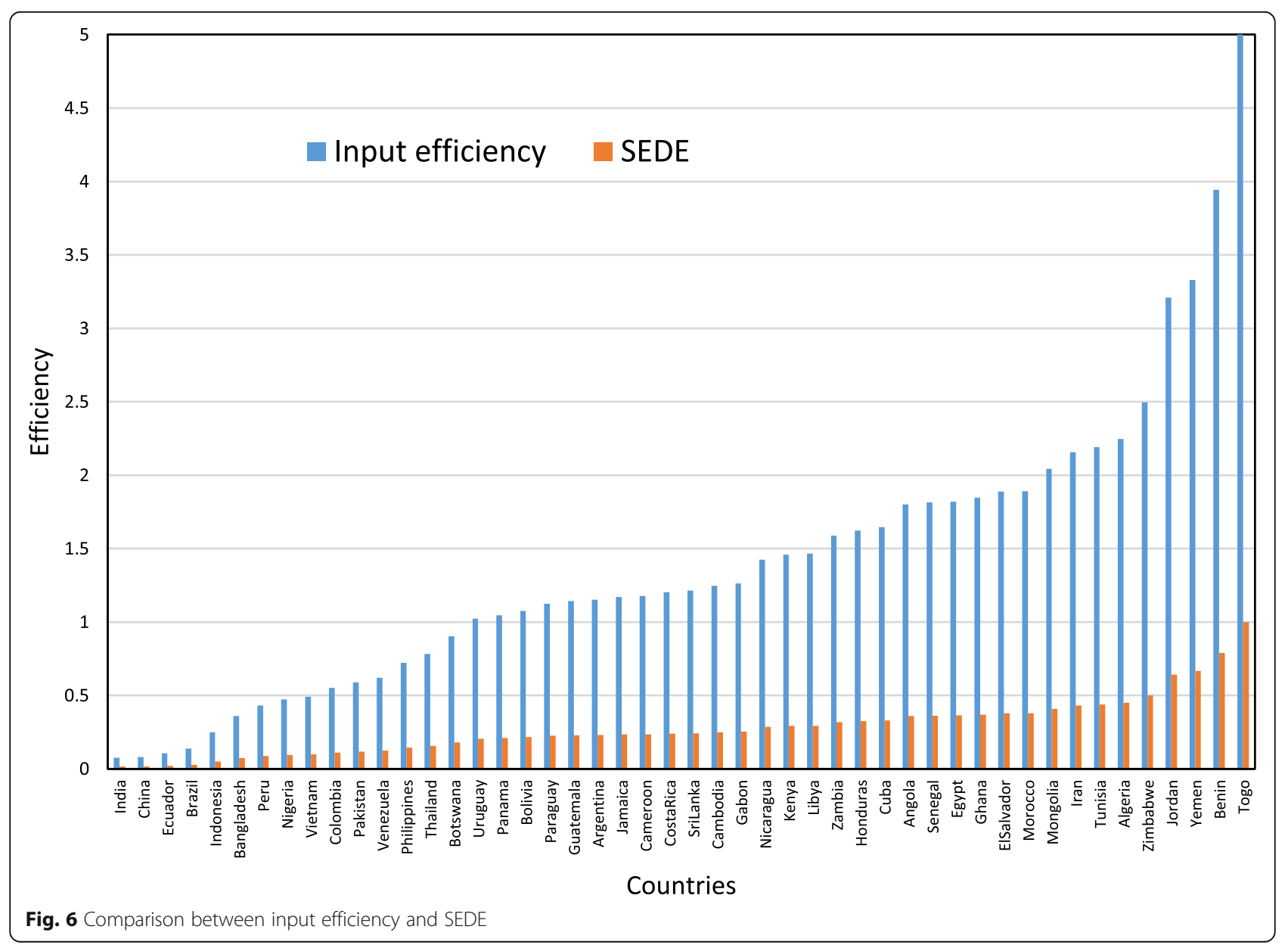


input and output parameters. In this research, the DEA result posits if a country is moving in a sustainable manner by using its resources in an efficient manner to achieve the targeted outputs. The SEDE for the various countries was compared with HDI and EDI to draw further inferences.

\section{Sensitivity analysis}

A sensitivity analysis was performed on the DEA model. Since it was an output-oriented model (i.e., the output is kept as the target), the DEA analysis was run for a $10 \%$ decrease and $10 \%$ increase in each of the input criteria, namely land availability, energy reserves, water availability, human capital, and nation's wealth for each country. Sensitivity analysis is performed to find the sensitivity of each of the input criteria. Though a few of these criteria are constant, yet to study its influence on the output criteria, a sensitivity analysis was carried out. For instance, if the land (which is considered to be constant) was found to be sensitive for a country, then it is very important that policymakers take extra care to draft policies and measures for making effective use of the available land leading to increased energy efficiency. The percentage change in the sustainable energy development efficiency was calculated for each input criteria and for each country and analyzed.

\section{Results \\ Fuzzy AHP}

The questionnaire for carrying out a pairwise comparison of each of the input criteria as well as the output criteria was given to seven experts. The experts were asked to rate each of the criteria against the other using a table (Table 1). The ratings of the pairwise comparison for the first expert are given in Table 5. Based on the expert's ratings, the consistency ratio (CR) was calculated. The $\mathrm{CR}$ value for the first expert was 0.098938 for the input criteria and 0.059787 for the output criteria. Similarly, the CR value was found for the seven experts. The $C R$ values for the seven experts are given in Table 6. It was found that the $\mathrm{CR}$ value for two experts was above 0.1 in either the input or output criteria, and hence the ratings were excluded. The ratings of the remaining five experts were then transformed to fuzzy weights using TFN scale (Table 2) for the first expert. The normalized non-fuzzy weights for the five input

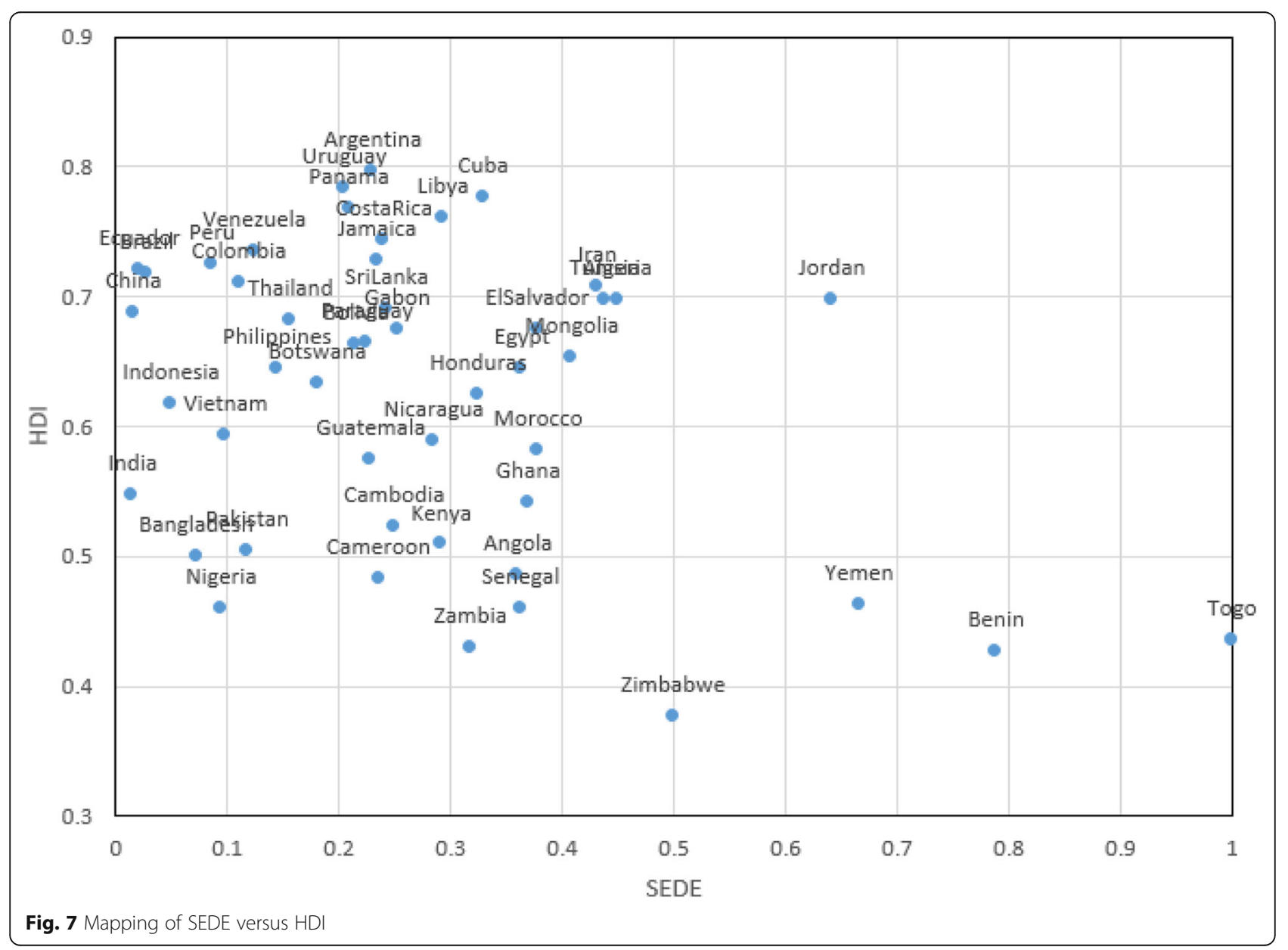


criteria were $0.125,0.155,0.207,0.238$, and 0.276 and for the output criteria $0.181,0.133,0.317,0.261$, and 0.107. In a similar manner, the weights for input and output criteria given by the five experts along with the average weights are given in Table 7.

From the weights, it was found that the maximum weight of 0.253 has been assigned to water availability followed by energy reserves with 0.249 . This indicated that among the resources, water availability and energy reserves were important and care has to be exerted to use these reserves in a prudent manner for sustainable development. Among the output indices, it was found that an environmental index with 0.285 is the most important, followed by a social index with 0.263 . Experts are of the opinion that the above indices are very important for sustainable development.

\section{DEA using AR-CCR output-oriented model}

The mean rating given by the five experts for the input and output criteria for sustainable energy development were used as multiplier constraints in the assurance region of the DEA model. The assurance region multipliers are given in Table 8 . As every country would like to maximize its indices with the available resources, the DEA model was aimed at maximizing the output criteria with an outputoriented model. The DEA analysis was carried out using DEA add-in Excel. The efficiency of the selected countries and the decomposition efficiency of the criteria are given in Table 9. The DEA model revealed a country's proximity to the efficient frontier. The sustainable energy development efficiency (SEDE) was calculated using the DEA model for the 48 countries and is presented in Fig. 3. Using the SEDE score, the countries are ranked. Togo was ranked 1 and identifies as the country lying in the efficient frontier. Among the output indices, it is found that the SEDE is maximum for an environmental index with 0.5688 followed by a technical index at 0.2495 . Considering the input criteria, it was found that with the available reserves, Togo has efficiently delivered the desired maximum output resulting in maximum SEDE.

Figure 4 presents a comparison between SEDE and each of the input criteria for various countries. It was clearly visible from the figure that Togo has less of input reserves, and by using that it was able to obtain the

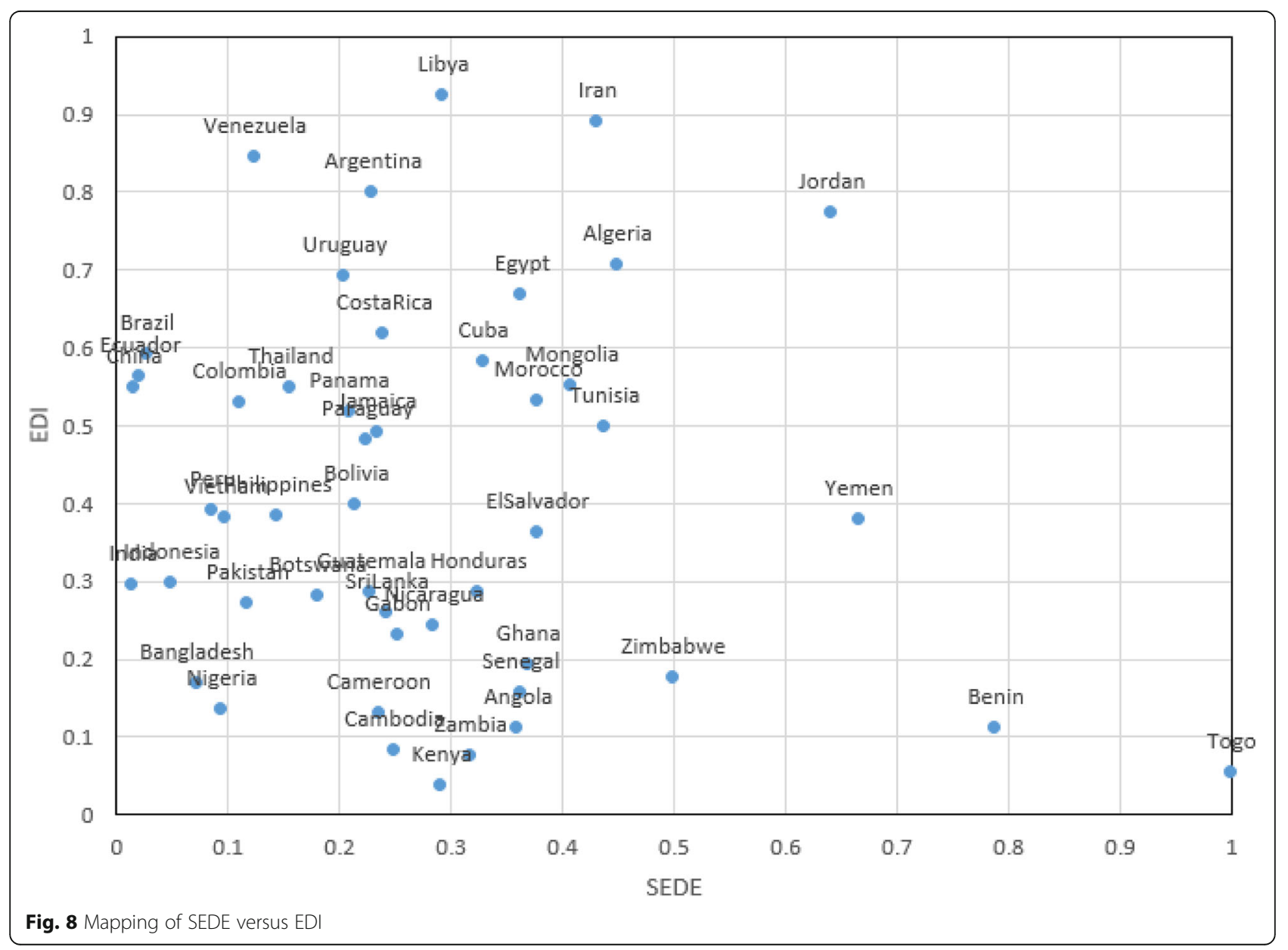




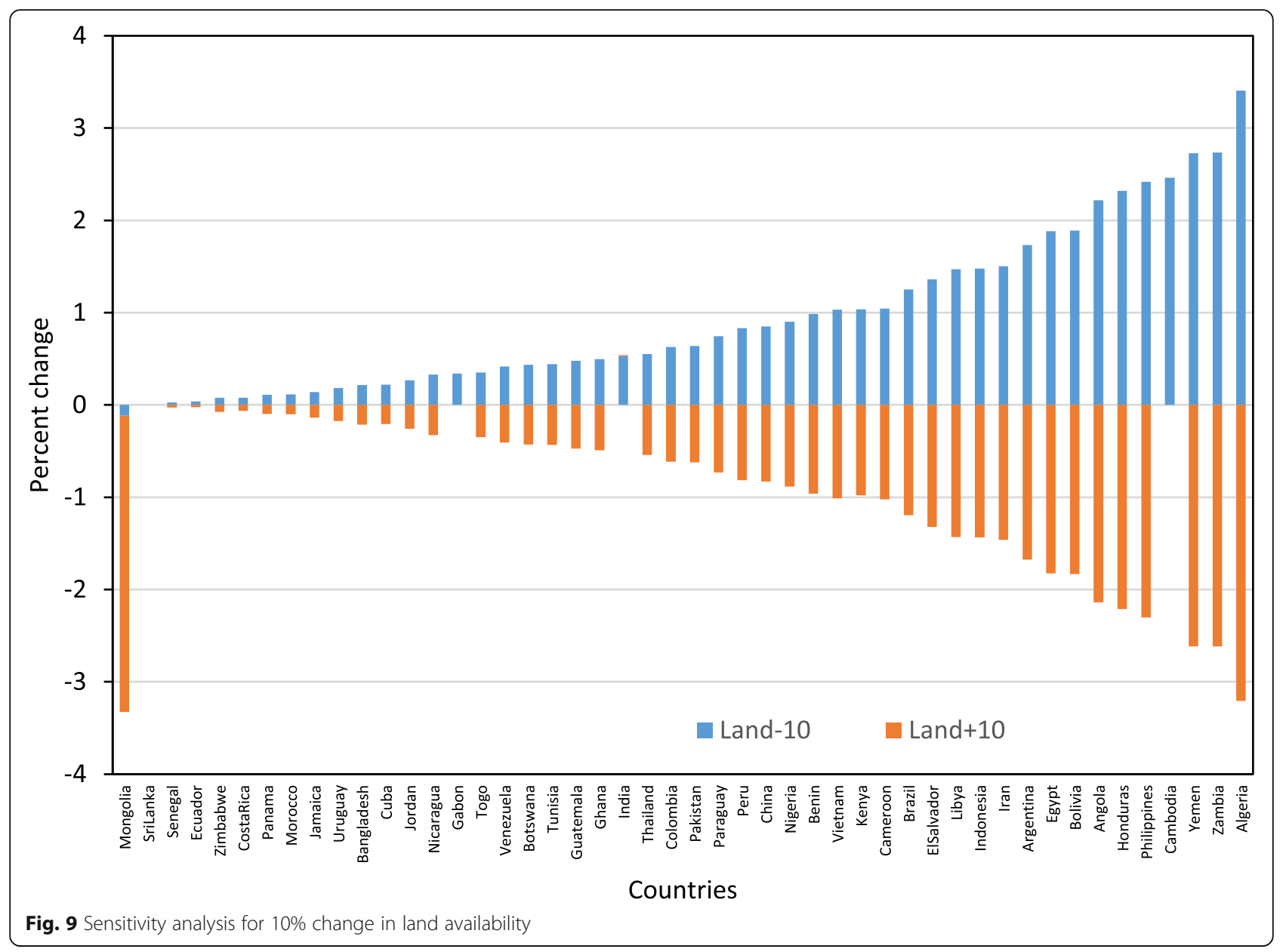

maximum output. Figure 5 presents a comparison between SEDE and output criteria for various countries. Though Angola has maximum effectiveness for the technical index yet considering all the output indices, Togo has the maximum SEDE.

As the DEA was run as an output-oriented model, a comparison was made between the aggregate input efficiency against SEDE for the various countries and is presented in Fig. 6. It was found that the countries which are getting maximum SEDE are those that are efficiently and conservatively using their resources. The figure clearly indicated that for a certain input of resources, there was more than a proportionate increase in sustainable energy development efficiency. This was due to the varying nature of the importance of the input criteria and the resources a country is endowed with.

A comparison was made between the SEDE and the Human Development Index (HDI), the SEDE and the Energy Development Index (EDI). The mapping of SEDE versus HDI is given in Fig.7. The figure clearly indicates that even though few countries have higher values for HDI yet they have very low values for SEDE. This indicates that such countries are not using their total resources in a holistic manner which is clearly visible in the SEDE score. Similarly, the mapping of SEDE versus EDI is plotted in Fig. 8. This figure clearly shows that countries are very good in their energy development index. But in the overall, is the resources of the country being used efficiently across all indices, it is found that there are lots of discrepancies. Few countries have got a very high EDI but the SEDE score is very low indicating inefficient use of their country's total resources.

\section{Sensitivity analysis}

The input criteria, namely land availability for Iran, were reduced by $10 \%$ and the DEA model was run. It was found that there was an increase of $1.5 \%$ in the SEDE score. However, when the land availability was increased by $10 \%$, it was found that SEDI decreased by $1.46 \%$. Similarly, the DEA was run for $10 \%$ change in land availability for Argentina, and it was found that when there was a $10 \%$ decrease, SEDE increased by $1.73 \%$ while when it was increased by $10 \%$, SEDE decreased by $1.67 \%$. Similarly, the DEA was run by first reducing land availability by $10 \%$ for each country and then by increasing by $10 \%$ of land availability. In each case, the 


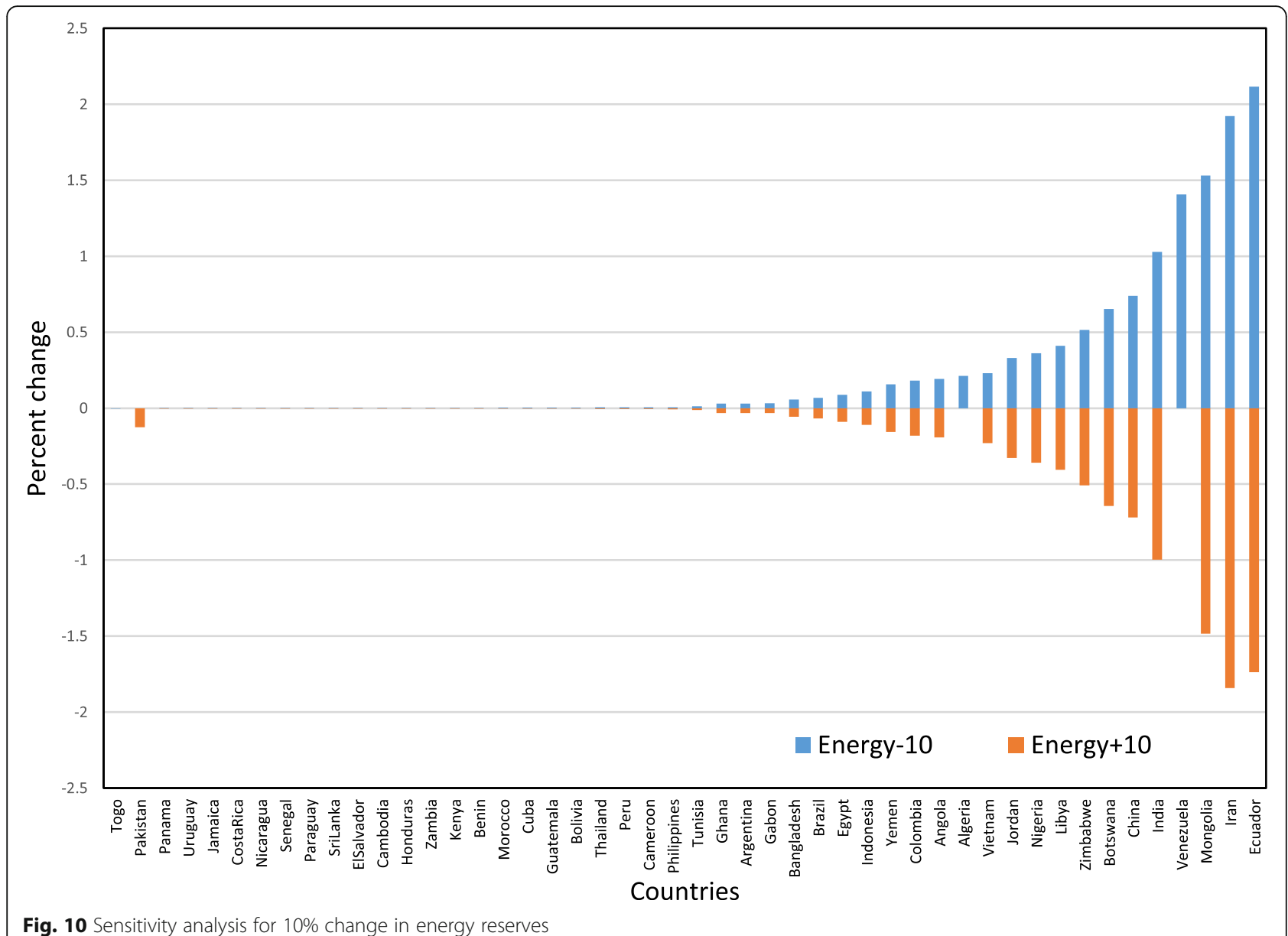

percentage change in SEDE was calculated and the values for all the countries are plotted in Fig. 9. A similar analysis was carried for each of the input criteria, and the percent change is plotted in Fig. 10 for energy reserves, Fig. 11 for water availability, Fig. 12 for human capital, and Fig. 13 for national wealth.

\section{Discussions}

The fuzzy weights given by the experts indicate that four out of five input resources are very important for sustainable development. Also, the experts have given almost equal weight for the four resources, namely water availability, energy reserves, nation's wealth, and human capital. However, of the four input criteria, water followed by the energy was given the maximum importance indicating these two resources are very vital for sustainable development. These resources have to be used in an effective manner so that higher indices are achieved for sustainable development. Among the output criteria, it was found that achieving higher environmental and social indices were very important for sustainable energy development. It was found that almost all experts have stated that environmental indices need to be carefully monitored for maximizing sustainable energy development. Three experts have indicated social indices as equally important. Experts were of mixed opinion when it comes to technical and economic indices. On the other hand, almost all experts have given the least weight for institutional indices.

As highlighted in the reports $[64,65]$, a country's natural resources should never become a curse. It is the responsibility of planners and policymakers to ensure the resources are being judiciously utilized for energy sustainability. In this research, the DEA analysis clearly highlights whether the country's resources are being efficiently used to obtain the desired outputs. The 5 topranked most efficient countries as per the order of ranking are Togo, Benin, Yemen, Jordan, and Zimbabwe. Though these countries have minimal resources, yet they are able to effectively transfer them to desired output as indicated by the higher indices in the environmental and social criteria. This is also clearly visible in Fig. 4. India is a highly populated country and is very high in human capital. But SEDE is very low for India and is ranked at 48th position. This clearly indicated that the resources are not being 


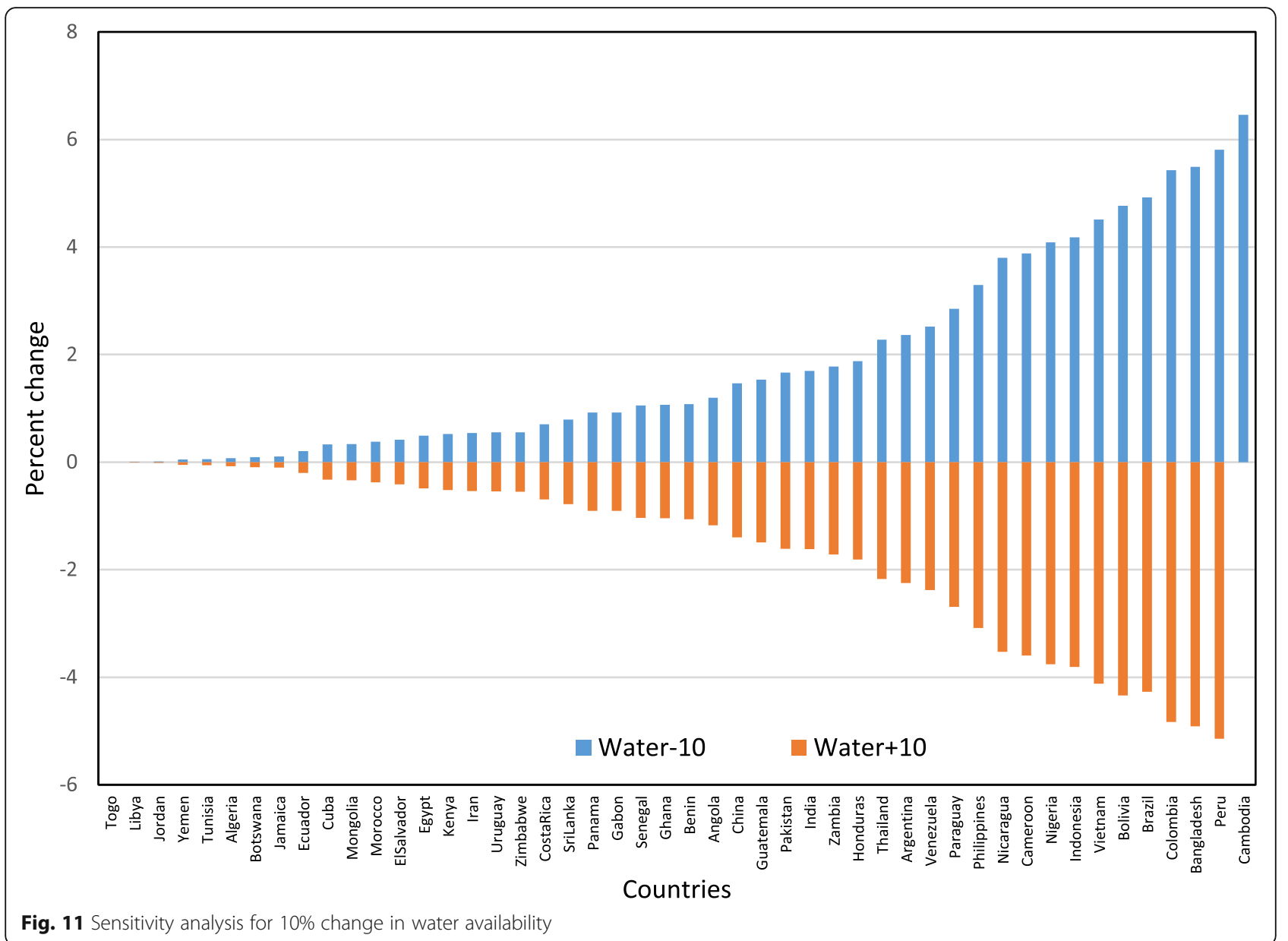

utilized in an efficient manner. Similarly, for China, the human capital is very high which itself becomes a burden, and the SEDE is very low at 47th position. Also, Ecuador is found to have maximum energy reserves, yet in terms of SEDE, it is ranked 46. Brazil has the maximum renewable water availability while as per SEDE it is ranked 45. This clearly indicates that it is not just sufficient to stock the resources but they need to be transformed into valuable output for achieving higher SEDE. Examining Togo which is at the frontier efficiency, it is found that the country's resources are very low. Yet with the available resources, it is able to deliver higher value in terms of the five indices which has led to maximum SEDE. Similar values are found for Benin, which also has minimal resources at its disposal. Yet with the minimal resources, it is delivering higher value in terms of output indices which has led to higher SEDE.

Figure 5 highlights the contribution of the five output indices for sustainable energy development. The weights from fuzzy AHP indicated that environmental index is very important followed by a social index. Togo has scored the maximum in the environmental index which could be one of the reasons for it to lie in the efficient frontier while when it comes to the social index it is far behind. As far as the social index is concerned, it is Iran which has been scored the maximum. With regard to technical index, Togo has scored fairly well while for economic index it was almost zero with 0.0085 . Benin is ranked at the second position with reference to SEDE. The reason could be it has performed fairly well with reference to environmental, social, and technical indices which are fairly important indices as perceived by the experts. Benin did not score well for economic and institutional index. Notwithstanding this, Benin scored the second position in SEDE. Algeria was found to have the maximum score for institutional index. However, since the weight assigned to the institutional index was less as per the experts' perception, and also since for all other indices it is far below in its position, it is found that the SEDE ranking for Algeria was at sixth. Comparing China and India, wherein both countries are high on human capital, it was found that their SEDE ranking was at 47th and 48th position respectively. China had scored the maximum with regard to economic index and fairly well in the social index while for all other indices it was very 


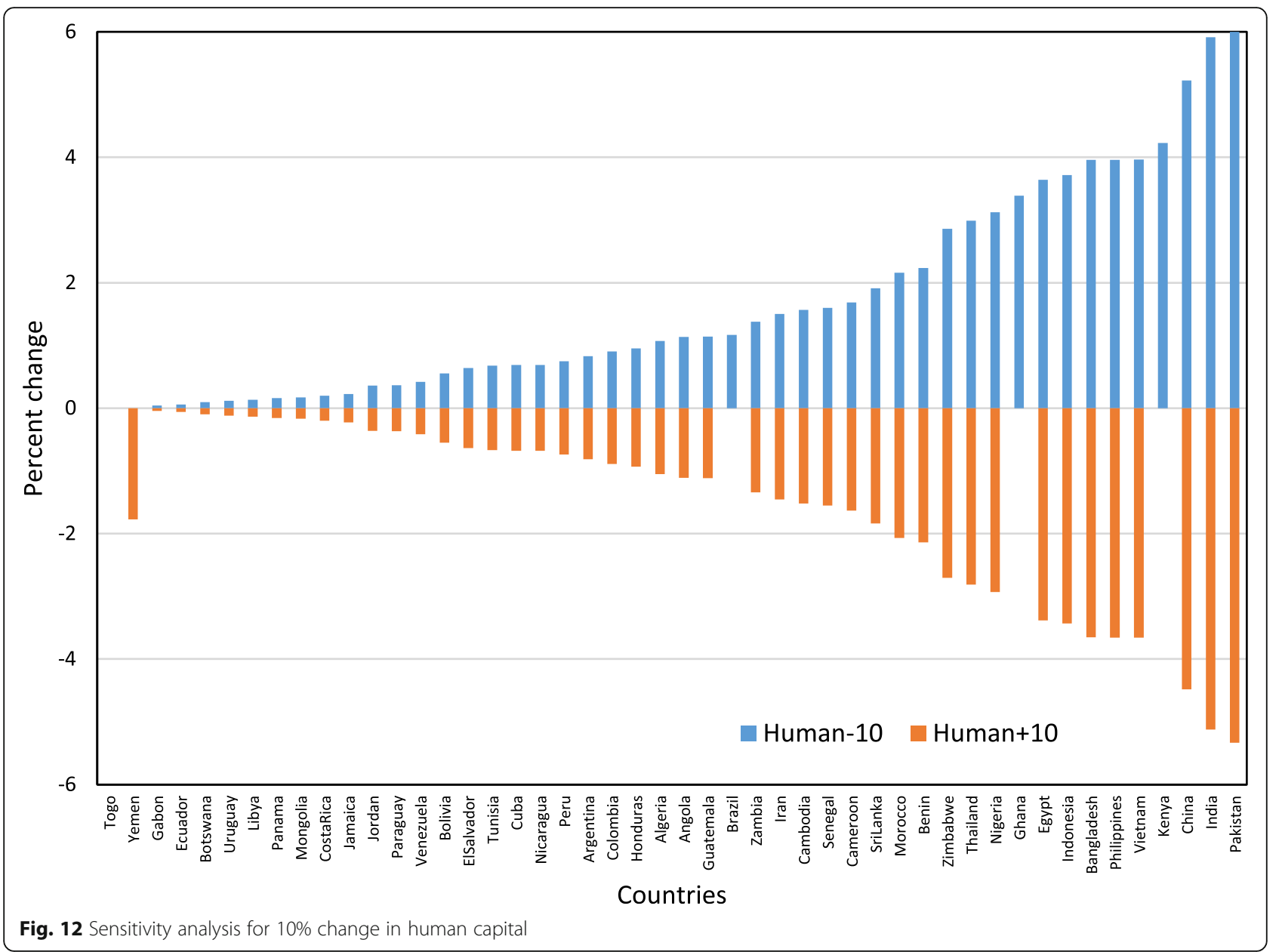

low. India was found to have scored maximum in the technical index while for all other indices it was very low. This indicates India needs to strengthen and make policies towards the environmental and social front so that if these two indices are increased there will be a drastic change in its SEDE position. Similarly, China also needs to take corrective action at its environmental front because it has scored the least in the environmental index, the index considered most important for SEDE by experts. The second action plan China needs to take is to find mechanisms for improving its technical and social index. This will immediately put China in a very competitive position in SEDE ranking. Comparing Figs. 4 and 5 for India, it is clearly visible that India has a remarkably large land area. However, from the results, it is seen that in spite of the land area being vast, it is not facilitating in achieving the desired outcome in terms of a maximum SEDE. As already indicated, resources should never become a liability [66, 67]. Immediate action is required for using this resource in an effective manner so as to enhance sustainability in terms of environmental and social indices for India.
The cross-examination of SEDE with HDI clearly indicates that China, Ecuador, Brazil, Venezuela, Argentina, Uruguay, and Panama have a very high HDI but a very low SEDE score. This indicates that these countries though are good in human development at a national level; they are not using their country's resources in an efficient manner. Immediate action has to be taken by these countries to ensure their resources are being used so that they can move towards overall sustainable energy development. Similarly, the mapping between SEDE and EDI clearly indicates few countries (for example, Libya, Iran, Venezuela, Argentina, Uruguay, and Egypt), which seem to be doing well with energy development, are not really progressing in a sustainable manner. Proactive measures have to be taken by the countries which are in the upperleft quadrant. For countries which are positioned in the lower-left quadrant, immediate measures have to be taken with a missionary zeal so that they are propelled to move towards the right.

Sensitivity analysis revealed the countries that were sensitive to certain indices. When there was a $10 \%$ change in 


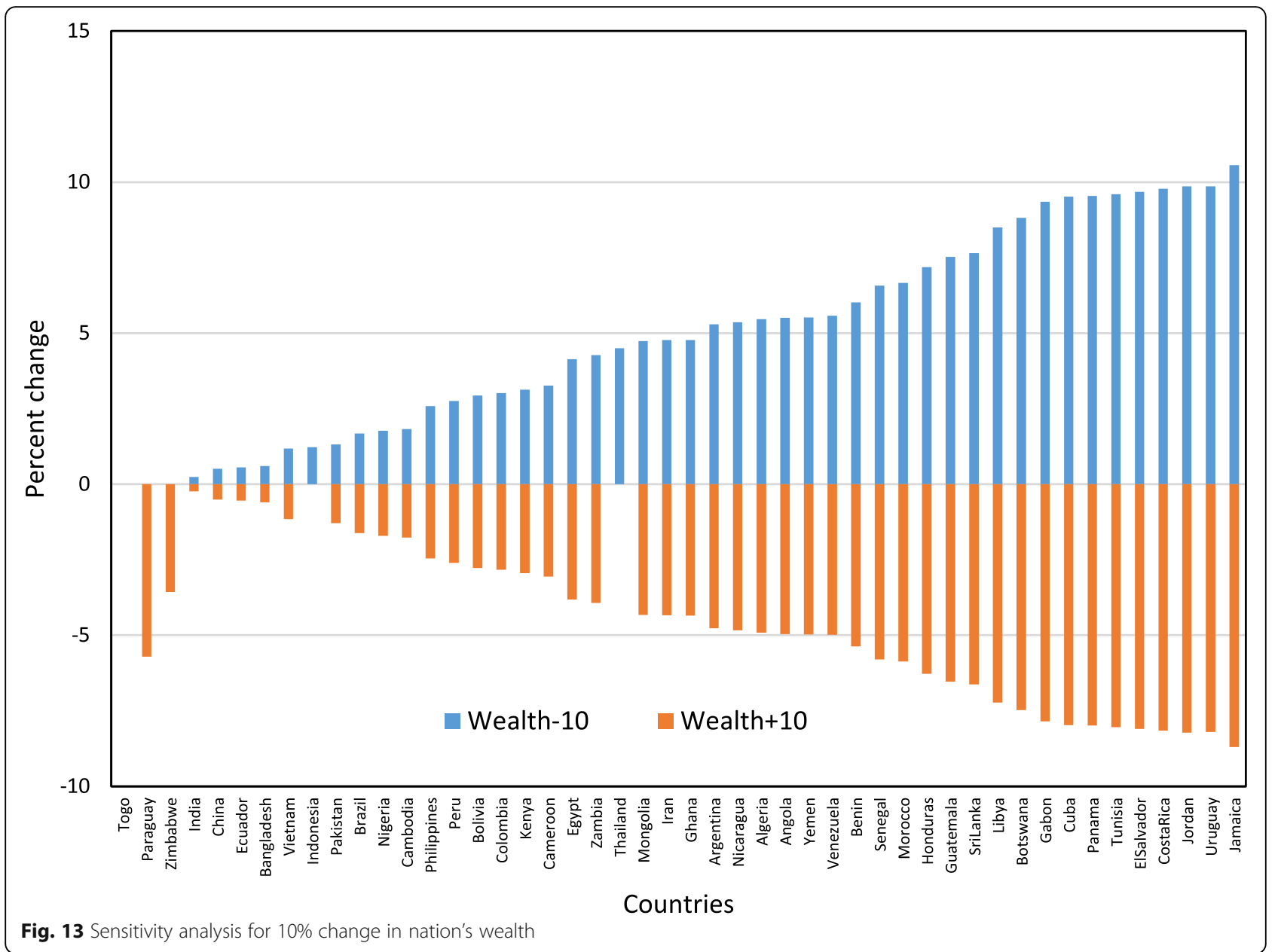

land availability, the percent change in SEDE was considerable for Algeria, followed by Yemen, Mongolia, Zambia, Philippines, Honduras, Angola, Egypt, and Bolivia. This indicated that for improving sustainable energy development efficiency, these countries need to draft policies and take measures in these criteria, namely land availability which is sensitive for their country. For a few countries, the percent change in SEDE was very minimal, namely Sri Lanka, Senegal, Ecuador, Zimbabwe, Costa Rica, and Panama. This shows that for improving SEDE among these countries, it is not advisable to concentrate on these criteria. Similarly, for Ecuador, Iran, Mongolia, Venezuela, India, China, Botswana, and Zimbabwe are advisable to concentrate on how energy resources are being utilized, since this criterion is very sensitive for these countries towards improving SEDE. However, the figure indicated that for several countries the utilization of energy reserves in contributing to SEDE is insensitive. When it comes to water, it is seen that several countries are sensitive. The most sensitive countries are Cambodia, Peru, Bangladesh, Colombia, Brazil, Bolivia, Vietnam, Indonesia, and Nigeria. These countries have to cautiously work on the water availability, so that they might exponentially increase their SEDE score. The countries for which water availability does not cause a major impact on SEDE are Libya, Jordan, Yemen, Tunisia, Algeria, Botswana, and Jamaica. As witnessed by the nature of population explosion in the developing countries, wherein China and India are the forerunners, it becomes doubly important to use human capital in an astute manner, since the human capital which is normally considered an asset in business parlance has become a liability as seen in the SEDE score. The utmost care and prudence need to be exercised by the policymakers and planners of these nations to convert this challenge into a strength. If strategic decisions are not taken immediately, though the country is endowed with rich resources, it will not be far off before the country moves slowly towards a marked rich-poor divide. The quality of life will deteriorate and the resources will be washed off by the heavy population. The other countries that fall in this category include Pakistan, Kenya, Vietnam, Philippines, Bangladesh, Indonesia, and Egypt. Among these countries, innovative measures to transform the human capital asset into potential output indicators that will 
lead to a higher SEDE score need to be immediately taken, since among these countries human capital criteria are sensitive with reference to SEDE. With regard to how sensitive is the nation's wealth in contributing to SEDE, it was found that almost all countries are sensitive. Figure 13 clearly shows a funnel-shaped structure indicating a nation's wealth is a very sensitive criterion for almost all countries. The countries which are very sensitive are Jamaica, Uruguay, Jordan, Costa Rica, El Salvador, Tunisia, Panama, Cuba, and Gabon. How the nation's wealth is being utilized is a very important factor for any country and this is what the results have also corroborated. Care has to be exercised during the country's budgeting that every amount that is being spent is contributing to the sustainable development of the nation.

\section{Conclusions}

The review of literature highlighted that indicators keep evolving over time and they need to be fine-tuned to the needs of a country depending on the nature of resources a country is endowed with. A cross-sectional study by comparing indicators across countries will serve as a benchmark for a country to progress in a sustainable manner which was undertaken in this research. The indices are compared across 48 countries. The research has identified the country's resources, namely as land availability, energy reserves, water availability, human capital, and nation's wealth as the input criteria and five output indicators as technical, economic, social, environmental, and institutional. Based on the expert's judgment, it was found that water availability and energy reserves were the most important resources for sustainable development. Among the output indices, it was found that environmental and social indices were considered the most important. Using the fuzzy weights, DEA was run and it was found that Togo reached the efficient frontier. This was because with the limited resources at its disposal Togo was able to score well in the environmental index which was identified as the most important index for sustainable development. The analysis also highlighted the position of each of the remaining 47 countries against the efficient frontier and also how the country can improve its position to reach the efficient frontier. For furthering SEDE, sensitivity analysis revealed which of the input resources, each country need to judiciously use, highlighting the sensitive input resource for each country. Nation's wealth was found to be sensitive among all the countries. In the future, a longitudinal study can be undertaken to find if there is a gradual increase in the indices over the years for the countries. This analysis will indicate if the country is gradually increasing on the path of sustainable development.

\section{Appendix}

Table 10 Urban sustainability index with indicator weights [22]

\begin{tabular}{lll}
\hline Component index & Subcomponents index & Indicator \\
\hline Urban status & $\begin{array}{l}\text { Socioeconomic } \\
\text { index }(0.41)\end{array}$ & Per capita GDP (0.36) \\
& $(0.50)$
\end{tabular}

Growth rate of GDP (0.20)

\begin{tabular}{|c|c|c|}
\hline & & $\begin{array}{l}\text { Percentage of population } \\
\text { below the poverty line } \\
(0.30)\end{array}$ \\
\hline & & $\begin{array}{l}\text { Educational investment } \\
\text { share in GDP }(0.14)\end{array}$ \\
\hline & \multirow[t]{6}{*}{$\begin{array}{l}\text { Environmental index } \\
(0.30)\end{array}$} & $\begin{array}{l}\text { Daily concentration of } \mathrm{SO} 2 \\
(0.20)\end{array}$ \\
\hline & & $\begin{array}{l}\text { Daily concentration of } \\
\text { particulate matter }\left(\mathrm{PM}_{10}\right) \\
(0.24)\end{array}$ \\
\hline & & $\begin{array}{l}\text { Percentage of water } \\
\text { meeting the drinking } \\
\text { quality standard (0.22) }\end{array}$ \\
\hline & & $\begin{array}{l}\text { Average concentration of } \\
\text { chemical oxygen demand } \\
\text { (COD) }(0.14)\end{array}$ \\
\hline & & $\begin{array}{l}\text { Area of arable land per } \\
\text { capita }(0.10)\end{array}$ \\
\hline & & $\begin{array}{l}\text { Per capita water resource } \\
(0.10)\end{array}$ \\
\hline & $\begin{array}{l}\text { Institutional capacity } \\
\text { index }(0.20)\end{array}$ & $\begin{array}{l}\text { Citizens' satisfaction with } \\
\text { their city }\end{array}$ \\
\hline \multirow[t]{5}{*}{$\begin{array}{l}\text { Urban } \\
\text { coordination } \\
\text { index }(0.34)\end{array}$} & $\begin{array}{l}\text { Coordination index of } \\
\text { economic and } \\
\text { environmental (0.34) }\end{array}$ & $\begin{array}{l}\text { Generation of waste water } \\
\text { per } 10,000 \text { CNY (Chinese } \\
\text { Yuan Renminbi) GDP (0.15) }\end{array}$ \\
\hline & & $\begin{array}{l}\text { Ratio of sewage treatment } \\
(0.20)\end{array}$ \\
\hline & & $\begin{array}{l}\text { Generation of SO2 per 10, } \\
000 \text { CNY GDP (0.15) }\end{array}$ \\
\hline & & $\begin{array}{l}\text { Recycling ratio of urban } \\
\text { wastes }(0.20)\end{array}$ \\
\hline & & $\begin{array}{l}\text { Environmental investment } \\
\text { share in GDP }(0.30)\end{array}$ \\
\hline \multirow[t]{6}{*}{$\begin{array}{l}\text { Urban potential } \\
\text { index }(0.25)\end{array}$} & $\begin{array}{l}\text { Ecological and } \\
\text { environmental } \\
\text { potential index (0.60) }\end{array}$ & $\begin{array}{l}\text { Ratio of renewable } \\
\text { resources consumption to } \\
\text { their generation }(0.20)\end{array}$ \\
\hline & & $\begin{array}{l}\text { Ratio of non-renewable re- } \\
\text { sources consumption to } \\
\text { their substitution }(0.25)\end{array}$ \\
\hline & & $\begin{array}{l}\text { Ratio of degradable } \\
\text { pollutant emission to their } \\
\text { purification }(0.25)\end{array}$ \\
\hline & & $\begin{array}{l}\text { Ratio of non-degradable } \\
\text { pollutant emission to their } \\
\text { purification }(0.30)\end{array}$ \\
\hline & $\begin{array}{l}\text { Welfare growth } \\
\text { potential index }(0.40)\end{array}$ & $\begin{array}{l}\text { Growth rate of basic needs } \\
\text { index }(0.60)\end{array}$ \\
\hline & & $\begin{array}{l}\text { Growth rate of income per } \\
\text { capita }(0.40)\end{array}$ \\
\hline
\end{tabular}


Table 11 Indicators for sustainable development [25]

\begin{tabular}{|c|c|c|}
\hline Theme & No & Indicator \\
\hline \multirow[t]{7}{*}{ Economic } & 1 & Average personal income \\
\hline & 2 & Female/male employment rate \\
\hline & 3 & Unemployment rate \\
\hline & 4 & Percentage of households with internet connection \\
\hline & 5 & $\begin{array}{l}\text { Percentage of public places with wireless internet } \\
\text { connections }\end{array}$ \\
\hline & 6 & $\begin{array}{l}\text { Average daily per capita water use (liter) (excluding } \\
\text { industrial use) }\end{array}$ \\
\hline & 7 & Electricity consumption per person \\
\hline \multirow[t]{23}{*}{ Social } & 8 & Urban population density \\
\hline & 9 & Female/male life expectancy \\
\hline & 10 & Number of households below the poverty line \\
\hline & 11 & Wealth gap \\
\hline & 12 & Crime rate \\
\hline & 13 & Annual casualties from public disasters \\
\hline & 14 & Annual number of transportation accidents \\
\hline & 15 & Per capita attendance of art and cultural activities \\
\hline & 16 & Average number of students per classroom \\
\hline & 17 & $\begin{array}{l}\text { Ratio of the population with a college level } \\
\text { education }\end{array}$ \\
\hline & 18 & $\begin{array}{l}\text { Rate of expansion of urban development lands } \\
\text { (including residential, commercial, industrial, and } \\
\text { public facilities) }\end{array}$ \\
\hline & 19 & Per capital floor area of private dwellings \\
\hline & 20 & Public facility area ratio to urban land areas \\
\hline & 21 & Per capita park and green areas \\
\hline & 22 & Riverside park and green area per person \\
\hline & 23 & Sewerage and waste removal efficiency \\
\hline & 24 & Rate of sanitary sewerage to total sewerage system \\
\hline & 25 & Car ownership rate \\
\hline & 26 & Motorcycle ownership rate \\
\hline & 27 & Areas covered with public transportation system \\
\hline & 28 & Per capita pedestrian walkway index \\
\hline & 29 & Per capita bikeway index \\
\hline & 30 & Number of bicycle kickstands \\
\hline \multirow[t]{10}{*}{ Environmental } & 31 & $\begin{array}{l}\text { Number of bird species living naturally in the } \\
\text { environment }\end{array}$ \\
\hline & 32 & $\begin{array}{l}\text { Number of fish species living naturally in the } \\
\text { environment }\end{array}$ \\
\hline & 33 & Green resource index \\
\hline & 34 & Permeable rate in urban lands \\
\hline & 35 & Number of days with PSI > 100 \\
\hline & 36 & Per capita $\mathrm{CO}_{2}$ emissions \\
\hline & 37 & Proportion of slightly polluted rivers \\
\hline & 38 & Reservoir water quality \\
\hline & 39 & Tap water quality \\
\hline & 40 & Per capita daily waste production \\
\hline
\end{tabular}

Table 11 Indicators for sustainable development [25]

(Continued)

\begin{tabular}{|c|c|c|}
\hline Theme & No & Indicator \\
\hline & 41 & Recycling ratio for solid waste \\
\hline & 42 & $\begin{array}{l}\text { Ratio of solid waste composted to total waste } \\
\text { production }\end{array}$ \\
\hline & 43 & $\begin{array}{l}\text { Utilization rate for renewable resources (bottom } \\
\text { ashes) }\end{array}$ \\
\hline \multirow[t]{8}{*}{ Institutional } & 44 & Enforcement of local environmental plans \\
\hline & 45 & $\begin{array}{l}\text { Citizen participation in major planning and } \\
\text { decision-making }\end{array}$ \\
\hline & 46 & $\begin{array}{l}\text { Joint international cooperation regarding } \\
\text { sustainable development (SD) }\end{array}$ \\
\hline & 47 & $\begin{array}{l}\text { Environmental and ecological budget ratio to total } \\
\text { budget }\end{array}$ \\
\hline & 48 & $\begin{array}{l}\text { Social welfare expenditure ratio to total } \\
\text { expenditure }\end{array}$ \\
\hline & 49 & $\begin{array}{l}\text { Government expenditure on pollution prevention } \\
\text { and resource recycling }\end{array}$ \\
\hline & 50 & $\begin{array}{l}\text { Ratio of completed assessments to initiated } \\
\text { assessments }\end{array}$ \\
\hline & 51 & $\begin{array}{l}\text { Appellate statistics of court cases related to } \\
\text { environmental pollution }\end{array}$ \\
\hline
\end{tabular}


Table 12 Indicators for energy and sustainable development [35]

\begin{tabular}{|c|c|c|}
\hline Factor & Variable & Intensity - measurement \\
\hline \multirow[t]{2}{*}{ Energy } & Final energy consumption (tera joules) (TJ) & $\begin{array}{l}\text { Final energy consumption per capita (giga joules per } \\
\text { person) }\end{array}$ \\
\hline & $\begin{array}{l}\text { Electricity consumption in industrial and residential sectors (kilowatt } \\
\text { hour) (kWh) }\end{array}$ & $\begin{array}{l}\text { Electricity consumption in the residential sector per capita } \\
\text { (kWh per person) }\end{array}$ \\
\hline \multirow[t]{2}{*}{$\begin{array}{l}\text { Economic } \\
\text { issue }\end{array}$} & GDP (million US\$2005) population & $\begin{array}{l}\text { Energy intensity: final energy consumption per GDP (TJ/ } \\
\text { million US\$2005) }\end{array}$ \\
\hline & $\begin{array}{l}\text { Number of industries (an industrial establishment has a minimum } \\
\text { of } 10 \text { employees and annual minimum production value of US } \$ 50,000 \text { ) }\end{array}$ & $\begin{array}{l}\text { Electricity consumption in the industrial sector per industry } \\
\text { (kWh per industry) }\end{array}$ \\
\hline $\begin{array}{l}\text { Environmental } \\
\text { issue }\end{array}$ & $\begin{array}{l}\text { Emissions: sulfur dioxide } \mathrm{SO}_{2}(\mathrm{ppb}) \text {, particulate matter } \\
\text { (microgram per cubic meter) }\left(\mu \mathrm{g} / \mathrm{m}^{3}\right), \mathrm{CO}_{2} \text { emissions (kilotons) }\end{array}$ & $\begin{array}{l}\text { Energy consumption per } \mathrm{CO}_{2} \text { emissions (TJ/kilotons) } \\
\mathrm{CO}_{2} \text { emissions per capita (tonnes/person) } \\
\mathrm{CO}_{2} \text { emissions per GDP (tonnes/million US\$2005) }\end{array}$ \\
\hline Social issue & $\mathrm{GINI}, \mathrm{HDI}$, urban density (population/km²) & \\
\hline
\end{tabular}

Table 13 Indicators for benchmarking cities [37]

\begin{tabular}{|c|c|c|c|}
\hline Theme & Scope of analysis & Sample & Reference \\
\hline \multirow[t]{8}{*}{ Energy and/or $\mathrm{CO}_{2}$ emissions } & Frequency analysis of energy data & CoM signatory cities & Kona et al. [68] \\
\hline & Energy consumption & 198 local units in the UK & Keirstead [69] \\
\hline & Carbon footprints & 12 metropolitan cities & Sovacool and Brown [70] \\
\hline & $\mathrm{CO}_{2}$ emissions & Nanjing (China) & Bi et al. [71] \\
\hline & Carbon footprint & 21 cities (Guangdong China) & Yajie et al. [72] \\
\hline & Carbon metabolism & Beijing (China) & Zhang et al. [73] \\
\hline & $\mathrm{CO}_{2}$ targets and measures & 8 low carbon cities (China) & Khanna et al. [74] \\
\hline & Scope of climate target setting & 8 European cities & Kramers et al. [75] \\
\hline \multirow[t]{3}{*}{ Transport } & Transport systems & 23 European cities & Alonso et al. [76] \\
\hline & ICT usage in transport & 26 major world cities & Debnath et al. [77] \\
\hline & Sustainable transport & Curitiba (Brazil) & Miranda et al. [78] \\
\hline \multirow[t]{3}{*}{ Waste } & Waste management & 3 cities (world) & Zaman and Lehmann [79] \\
\hline & Urban waste management & 14 Greek municipalities & Karagiannidis et al. [80] \\
\hline & Sustainable waste management & 5 cities (world) & Wilson et al. [81] \\
\hline Water & Water treatment options & Ningbo (China) & Wu et al. [82] \\
\hline Energy-water-carbon nexus & Urban water systems & 4 European cities & Venkatesh et al. [83] \\
\hline Socio-economic power & Socio-economic power & 35 major world cities & Arribas-Bel et al. [84] \\
\hline \multirow[t]{6}{*}{ Multidisciplinary (sustainability) } & Locally integrated energy sectors & Ormoz Municipality (Slovenia) & Kostevšek et al. [34] \\
\hline & Low-carbon eco-cities & Not applied to any city & Zhou et al. [33] \\
\hline & Environment social economic pillars & Island energy structure & Afgan et al. [85] \\
\hline & Green cities (limited energy focus) & Various cities (world) & $\begin{array}{l}\text { Siemens (http://sg.siemens.com/city_of_the } \\
\text { _future/_docs/gci_report_summary.pdf) }\end{array}$ \\
\hline & Environment and quality of life & Australian cities & Trigg et al. [32] \\
\hline & Energy scenarios with SDEWES Index & 22 Mediterranean port cities & Kılkış [37] \\
\hline
\end{tabular}


Table 14 ISED classified according to the indirect, direct driving force, and state [46]

\begin{tabular}{ll}
\hline Indirect driving force & Direct driving force \\
\hline 1. Population: total; urban & $\begin{array}{l}\text { 14. Energy use per unit of GDP } \\
\text { 2. GDP per capita }\end{array}$ \\
$\begin{array}{l}\text { 15. Expenditure on energy sector: total investments, } \\
\text { environmental control, hydrocarbon exploration and } \\
\text { development, R\&D, net energy import expenses }\end{array}$
\end{tabular}

3. End-use energy prices with and without tax/subsidy

4. Shares of sectors in GDP value added

5. Distance traveled per capita: total, by urban public transport mode

6. Freight transport activity: total, by mode

7. Floor area per capita

8. Manufacturing value added by selected energy intensive industries

9. Energy intensity: manufacturing, transportation, agriculture, commercial and public services, residential sector

10. Final energy intensity of selected energy intensive products

11. Energy mix: final energy, electricity generation, and primary energy supply

12. Energy supply efficiency: fossil fuel efficiency for electricity generation

13. Status of deployment of pollution abatement technologies: extent of use, average performance

19. Income inequality

21. Fraction of disposal income spent on fuels (total population, 20\% poorest)

23. Quantities of air pollutant emissions-sulfur dioxide $\left(\mathrm{SO}_{2}\right)$, nitrous oxides (NOx), particulates, $\mathrm{CO}_{2}$, volatile organic compounds (VOC)

26. Quantities of greenhouse gas emissions

27. Radionuclides in atmospheric radioactive discharges

28. Discharges into water basins: waste/storm water, radionuclides, oil into coastal waters

\section{Generation of solid waste}

31. Generation of radioactive waste

33. Land area taken up by energy facilities and infrastructure

35. Fraction of technically exploitable capability of hydropower currently not in use

36. Proven recoverable fossil fuel reserves

38. Proven uranium reserves

40. Intensity of use of forest resources as fuelwood
State

16. Energy use per capita

17. Indigenous energy production

18. Net energy import dependence

22. Fraction of households: heavily dependent on non-commercial energy; without electricity

24. Ambient concentration of pollutants in urban areas: $\mathrm{SO}_{2}, \mathrm{NOx}$, suspended particulates, $\mathrm{CO}_{2}$, ozone

25. Land area where acidification exceeds critical load

30. Accumulated quantity of solid wastes to be managed

32. Quantity of accumulated radioactive wastes awaiting disposal

34. Fatalities due to accidents with breakdown by fuel chains

37. Life time of proven fossil fuel reserves

39. Life time of proven uranium reserves

41. Rate of deforestation

20. Ratio of daily disposable income/private consumption per capita of $20 \%$ poorest population to the prices of electricity and major household fuels 
Table 15 List of energy indicators for sustainable development (EISD) [3]

\begin{tabular}{|c|c|c|c|c|c|}
\hline Indicator & Theme & Subtheme & Code & Energy indicator & Components \\
\hline \multirow[t]{2}{*}{ Social } & Equity & Accessibility & SOC1 & $\begin{array}{l}\text { Share of households (or population) } \\
\text { without electricity or commercial energy, } \\
\text { or heavily dependent on non-commercial } \\
\text { energy }\end{array}$ & $\begin{array}{l}\checkmark \text { Households (or population) without electricity } \\
\text { or commercial energy, or heavily dependent on } \\
\text { non-commercial energy } \\
\checkmark \text { Total number of households or population }\end{array}$ \\
\hline & & Affordability & $\mathrm{SOC2}$ & $\begin{array}{l}\text { Share of household income spent on fuel } \\
\text { and electricity }\end{array}$ & $\begin{array}{l}\checkmark \text { Household income spent on fuel and } \\
\text { electricity } \\
\checkmark \text { Household income (total and poorest 20\% of } \\
\text { population) }\end{array}$ \\
\hline
\end{tabular}

Disparities

SOC3 Household energy use for each income group and corresponding fuel mix
Health Safety

Economic
Overall use

production patterns
En

SOC4 Accident fatalities per energy produced by fuel chain

ECO1 Energy use per capita

Supply efficiency

$\mathrm{ECO} 3$

Efficiency of energy conversion and distribution

Production

ECO4 Reserves-to production ratio

ECO5 Resources-to production ratio

End use

ECO6 Industrial energy intensities

$\mathrm{ECO} 7$ Agricultural energy intensities

ECO8 Service/commercial energy intensities

ECO9 Household energy intensities

ECO10 Transport energy intensities

Diversification (fuel mix) ECO11 Fuel shares in energy and electricity

ECO12 Non-carbon energy share in energy and electricity

ECO13 Renewable energy share in energy and electricity $\checkmark$ Energy use per household for each income group (quintiles)

$\checkmark$ Household income for each income group (quintiles)

$\checkmark$ Corresponding fuel mix for each income group (quintiles)

$\checkmark$ Annual fatalities by fuel chain $\checkmark$ Annual energy produced

$\checkmark$ Energy use (total primary energy supply, total final consumption and electricity use) $\checkmark$ Total population

$\checkmark$ Energy use (total primary energy supply, total final consumption and electricity use) $\checkmark$ GDP

$\checkmark$ Losses in transformation systems including losses in electricity generation, transmission and distribution

$\checkmark$ Proven recoverable reserves

$\checkmark$ Total energy production

$\checkmark$ Total estimated resources

$\checkmark$ Total energy production

$\checkmark$ Energy use in industrial sector and by manufacturing branch

$\checkmark$ Corresponding value added

$\checkmark$ Energy use in agricultural sector

$\checkmark$ Corresponding value added

$\checkmark$ Energy use in service/ commercial sector $\checkmark$ Corresponding value added

$\checkmark$ Energy use in households and by key end use $\checkmark$ Number of households, floor area, persons per household, appliance ownership

$\checkmark$ Energy use in passenger travel and freight sectors and by mode

$\checkmark$ Passenger-km travel and tonne-km freight and by mode

$\checkmark$ Primary energy supply and final consumption, electricity generation and generating capacity by fuel type

$\checkmark$ Total primary energy supply, total final consumption, total electricity generation and total generating capacity

$\checkmark$ Primary supply, electricity generation and generating capacity by non-carbon energy $\checkmark$ Total primary energy supply, total electricity generation and total generating capacity

$\checkmark$ Primary energy supply, final consumption and electricity generation and generating capacity by renewable energy

$\checkmark$ Total primary energy supply, total final consumption, total electricity generation and total generating capacity

$\checkmark$ Energy prices (with and without tax/ subsidy) 
Table 15 List of energy indicators for sustainable development (EISD) [3] (Continued)

\begin{tabular}{|c|c|c|c|c|c|}
\hline Indicator & Theme & Subtheme & Code & Energy indicator & Components \\
\hline & Security & Imports & ECO15 & Net energy import dependency & $\begin{array}{l}\text { Energy imports } \\
\checkmark \text { Total primary energy supply }\end{array}$ \\
\hline & & Strategic fuel stocks & ECO16 & $\begin{array}{l}\text { Stocks of critical fuels per corresponding } \\
\text { fuel consumption }\end{array}$ & $\begin{array}{l}\checkmark \text { Stocks of critical fuel (oil, gas, etc.) } \\
\checkmark \text { Critical fuel consumption }\end{array}$ \\
\hline \multirow[t]{10}{*}{ Environmental } & Atmosphere & Climate change & ENV1 & $\begin{array}{l}\text { Green-house gas (GHG) emissions from } \\
\text { energy production and use per capita and } \\
\text { per unit of GDP }\end{array}$ & $\begin{array}{l}\checkmark \text { GHG emissions from energy production and } \\
\text { use } \\
\checkmark \text { Population and GDP }\end{array}$ \\
\hline & & Air quality & ENV2 & $\begin{array}{l}\text { Ambient concentrations of air pollutants in } \\
\text { urban areas }\end{array}$ & $\checkmark$ Concentrations of pollutants in air \\
\hline & Water & Water quality & ENV3 & $\begin{array}{l}\text { Air pollutant emissions from energy } \\
\text { systems }\end{array}$ & $\checkmark$ Air pollutant emissions \\
\hline & Land & Soil quality & ENV4 & $\begin{array}{l}\text { Contaminant discharges in liquid effluents } \\
\text { from energy systems including oil } \\
\text { discharges }\end{array}$ & $\checkmark$ Contaminant discharges in liquid effluents \\
\hline & & Forest & ENV5 & $\begin{array}{l}\text { Soil area where acidification exceeds critical } \\
\text { load }\end{array}$ & $\begin{array}{l}\checkmark \text { Affected soil area } \\
\checkmark \text { Critical load }\end{array}$ \\
\hline & & $\begin{array}{l}\text { Solid waste generation } \\
\text { and management }\end{array}$ & ENV6 & $\begin{array}{l}\text { Rate of deforestation attributed to energy } \\
\text { use }\end{array}$ & $\checkmark$ Forest area at two different times \\
\hline & & & ENV7 & $\begin{array}{l}\text { Ratio of solid waste generation to units of } \\
\text { energy produced }\end{array}$ & $\begin{array}{l}\checkmark \text { Amount of solid waste } \\
\checkmark \text { Energy produced }\end{array}$ \\
\hline & & & ENV8 & $\begin{array}{l}\text { Ratio of solid waste properly disposed to } \\
\text { total generated solid waste }\end{array}$ & $\begin{array}{l}\checkmark \text { Amount of solid waste properly disposed of } \\
\checkmark \text { Total amount of solid waste }\end{array}$ \\
\hline & & & ENV9 & $\begin{array}{l}\text { Ratio of solid radioactive waste to units of } \\
\text { energy produced }\end{array}$ & $\begin{array}{l}\checkmark \text { Amount of radioactive waste (cumulative for } \\
\text { a selected period of time) } \\
\checkmark \text { Energy produced }\end{array}$ \\
\hline & & & ENV10 & $\begin{array}{l}\text { Ratio of solid radioactive waste awaiting } \\
\text { disposal to total generated solid } \\
\text { radioactive waste }\end{array}$ & $\begin{array}{l}\checkmark \text { Amount of radioactive waste awaiting } \\
\text { disposal } \\
\checkmark \text { Total volume of radioactive waste }\end{array}$ \\
\hline
\end{tabular}

Table 16 Energy indices for sustainable development [52]

\begin{tabular}{lll}
\hline Theme & No & Sub-indicator \\
\hline Economy & 1 & Energy cost \\
& 2 & Investment \\
& 3 & Plant efficiency \\
& 4 & Industrial, household, and commercial energy intensities \\
Social & 5 & Energy use per household \\
& 6 & Share of household income spent on fuel and electricity \\
& 7 & Number of injured per energy produced \\
& 8 & Number of working hours per energy produced \\
Ecology & 9 & $\mathrm{CO}_{2}$ emission per energy produced \\
& 10 & $\mathrm{CO}_{2}$ emission per capita \\
& 11 & $\mathrm{NOx}$ emission per energy produced \\
& 12 & $\mathrm{NOx}$ emission per capita \\
\hline
\end{tabular}


Table 17 Energy indicators for sustainable development in residential buildings [54]

\begin{tabular}{|c|c|c|c|}
\hline Theme & Code & Sub indicator & Definition \\
\hline \multirow[t]{4}{*}{ Economic } & $\mathrm{Ecl}_{\mathrm{ec}}$ & Electricity consumption & $\begin{array}{l}\text { Total annual electricity consumption of the objects divided by the total } \\
\text { number of objects }\end{array}$ \\
\hline & $\mathrm{ECl}_{\mathrm{tc}}$ & Heat consumed for space heating & $\begin{array}{l}\text { Total annual heat consumption of the objects divided by the total heated } \\
\text { area }\end{array}$ \\
\hline & Ecl hwe & Hot water consumption & Estimated consumption of hot water per person living in the household \\
\hline & Eclecc & $\begin{array}{l}\text { Electricity consumed to meet household } \\
\text { cooking needs }\end{array}$ & $\begin{array}{l}\text { Average specific annual consumption of electricity used to meet household } \\
\text { cooking needs }\end{array}$ \\
\hline \multirow[t]{4}{*}{ Social } & Sol $_{\text {Is }}$ & Living space area per person & Total area of a building divided by the total number of household members \\
\hline & Solac & Air-conditioning use & Share of buildings where air-conditioning is used \\
\hline & Sol $_{\mathrm{dw}}$ & Dishwasher use & Share of buildings where dishwashers are used \\
\hline & Solic $_{\text {ic }}$ & Indoor comfort & Share of households that are satisfied with indoor comfort \\
\hline \multirow[t]{3}{*}{ Environmental } & Enlat & Air temperature & Average daily air temperature in the living room \\
\hline & $\mathrm{EnI}_{\mathrm{rh}}$ & Relative humidity & Average daily relative humidity in the living room \\
\hline & $\mathrm{Enl}_{\mathrm{CO} 2}$ & $\mathrm{CO}_{2}$ concentration & $\begin{array}{l}\text { Average daily concentration of } \mathrm{CO}_{2} \text { in the living room during the winter } \\
\text { period }\end{array}$ \\
\hline
\end{tabular}

Table 18 Set of indicators for sustainable energy development [55]

\begin{tabular}{|c|c|c|c|}
\hline Dimension & Code & Indicator & Data required \\
\hline \multirow[t]{3}{*}{ Technical } & TEC1 & $\begin{array}{l}\text { Share of depletable (non-renewable) energies } \\
\text { in total primary energy supply (TPES) }\end{array}$ & TPES; total consumption of non-renewable energies \\
\hline & TEC2 & Depletion coefficient of local energy resources & $\begin{array}{l}\text { Domestic production values of coal, oil, natural gas and solid fuels; proved } \\
\text { reserves of coal, oil, natural gas; total forest area; total land area }\end{array}$ \\
\hline & TEC3 & Overall system conversion efficiency & Total final consumption (TFC); TPES \\
\hline \multirow[t]{3}{*}{ Economic } & ECO1 & $\begin{array}{l}\text { Per capita consumption of commercial } \\
\text { energies }\end{array}$ & Total commercial energy consumption; population \\
\hline & ECO2 & Final energy intensity & TFC; GDP in purchasing power parity (PPP) \\
\hline & $\mathrm{ECO} 3$ & Share of productive use of energy & TFC; residential energy consumption \\
\hline \multirow[t]{2}{*}{ Social } & SOC1 & $\begin{array}{l}\text { Per capita consumption of clean energies in } \\
\text { the residential sector }\end{array}$ & Total clean energy consumption in the residential sector; population \\
\hline & SOC2 & Income inequality & Gini coefficient \\
\hline \multirow[t]{2}{*}{ Environmental } & ENV1 & $\begin{array}{l}\text { Share of "dirty fuels" in residential energy } \\
\text { consumption }\end{array}$ & $\begin{array}{l}\text { Total consumption of coal, peat, crude oil, solid fuels; residential energy } \\
\text { consumption (REC) }\end{array}$ \\
\hline & ENV2 & Carbon intensity & TPES; total CO2 emissions from fuel combustion \\
\hline Institutional & INS1 & Overall self sufficiency & TPES; indigenous production \\
\hline
\end{tabular}




\section{Abbreviations}

AHP: Analytical hierarchical process; AR-CCR: Assurance region Charnes, Cooper, and Rhodes; CNY: Chinese Yuan Renminbi (currency unit); $\mathrm{CO}_{2}$ : Carbon dioxide; $\mathrm{COD}$ : Chemical oxygen demand; CR: Consistency ratio; DEA: Data envelopment analysis; ECLAC: Economic Commission for Latin America and the Caribbean; EDI: Energy Development Index; EISD: Energy indicators for sustainable development; EPI: Environmental Performance Index; ESI: Environmental Sustainability Index; GDP: Gross domestic product; GHG: Greenhouse gas; GTZ: German Technical Cooperation Agency; HDI: Human Development Index; HPI: Human Poverty Index; IAEA: International Atomic Energy Agency; IEA: International Energy Agency; ISED: Indicators for Sustainable Energy Development; MCDM: Multi-criteria decision making; MDG: Millennium Development Goals; NOx: Nitrous oxides; OLADE: Latin American Energy Organization; PM: Particulate matter; PPP: Purchasing power parity; REC: Residential energy consumption; SD: Sustainable development; SDEWES: Sustainable Development of Energy, Water and Environment Systems; SEDE: Sustainable energy development efficiency; SEDI: Sustainability Energy Development Index; $\mathrm{SO}_{2}$ : Sulfur dioxide; TFC: Total final consumption; TFN: Triangular fuzzy scale; TJ: Tera joules; TPES: Total primary energy supply; UN: United Nations; UNDESA: United Nations Department of Economic and Social Affairs; UNDP: United Nations Development Program; VOC: Volatile organic compounds

\section{Acknowledgements}

The author is thankful to the experts who participated in this study as well as the fellow researchers in the University for their feedback and suggestions.

\section{Authors' contributions}

The theoretical framework, research design, data analysis, and inferences drawn was solely carried out by the author LS. The author(s) read and approved the final manuscript.

\section{Funding}

This research did not receive any specific grant from funding agencies in the public, commercial, or not-for-profit sectors.

\section{Availability of data and materials}

The data used for this research will be made available upon request. Also the data is available on relevant authorities' webpages.

\section{Ethics approval and consent to participate}

Not applicable.

\section{Consent for publication}

Not applicable.

\section{Competing interests}

The authors declare that they have no competing interests.

Received: 5 June 2019 Accepted: 2 March 2020

Published online: 17 March 2020

\section{References}

1. WCED (1987) World commission on environment and development: our common future. Oxford University Press, Oxford

2. Oshima HT (1986) The transition from an agricultural to an industrial economy in East Asia. Econ Dev Cult Change 34:783-809. https://doi.org/10. 2307/1153732

3. IAEA (2005) Energy indicators for sustainable development: guidelines and methodologies.

4. https://data.worldbank.org/indicator. Renewable energy consumption (\% of total final energy consumption) | Data https://data.worldbank.org/indicator/ EG.FEC.RNEW.ZS?locations $=1 \mathrm{~N}$

5. https://www.worldfinance.com/markets/top-5-of-the-fastest-growingindustries-in-the-world. Top 5 of the fastest-growing industries in the world | World Finance

6. Venables AJ (2016) Using natural resources for development: why has it proven so difficult? J Econ Perspect 30:161-183. https://doi.org/10.2307/ 43710015
7. D'Amato D, Korhonen J, Toppinen A (2019) Circular, green, and bio economy: how do companies in land-use intensive sectors align with sustainability concepts? Ecol Econ 158:116-133. https://doi.org/10.1016/J. ECOLECON.2018.12.026

8. Ge Y, Zhi Q (2016) Literature review: the green economy, clean energy policy and employment. Energy Procedia 88:257-264. https://doi.org/10. 1016/J.EGYPRO.2016.06.159

9. Tiba S, Omri A (2016) Literature survey on the relationships between energy variables, environment and economic growth. Munich Pers RePEc Arch.

10. Singh RK, Murty HR, Gupta SK, Dikshit AK (2012) An overview of sustainability assessment methodologies. Ecol Indic 9:189-212. https://doi. org/10.1016/j.ecolind.2008.05.011

11. Pintér L, Hardi P, Bartelmus P (2005) Sustainable development indicators prepared for the United Nations Division for Sustainable Development (UNDSD) proposals for a way forward

12. UNECE J (2013) Framework and suggested indicators to measure sustainable development prepared by the Joint UNECE/Eurostat/OECD Task Force on Measuring Sustainable Development.

13. Olade (1997) Energy and sustainable development in Latin America and the Caribbean: guide for energy policymaking.

14. Nussbaumer P, Bazilian M, Modi V (2012) Measuring energy poverty: focusing on what matters. Renew Sustain Energy Rev 16:231-243. https:// doi.org/10.1016/J.RSER.2011.07.150

15. Vera I, Langlois $L$ (2007) Energy indicators for sustainable development. Energy 32:875-882. https://doi.org/10.1016/J.ENERGY.2006.08.006

16. IEA (2004) World Energy Outlook.

17. Esty DC, Srebotnjak T, Goodall M, Andonov B, Campbell K, Gregg K, et al (2005) Environmental sustainability index benchmarking national environmental stewardship.

18. Bossel H (1999) Indicators for sustainable development: theory, method, applications

19. Cochrane P (2006) Exploring cultural capital and its importance in sustainable development. Ecol Econ 57:318-330

20. Pugh C (1996) Sustainability, the environment and urbanization. England Earthscan, London

21. Hardoy J, Mitlin D, Satterthwaite D (1992) Environmental problems in Third World cities

22. Zhang M (2002) Measuring urban sustainability in China

23. van MP D, Mingshun Z (2005) Sustainability indices as a tool for urban managers, evidence from four medium-sized Chinese cities. Environ Impact Assess Rev 25:667-688. https://doi.org/10.1016/J.EIAR.2004.10.001

24. Andriantiatsaholiniaina LA, Kouikoglou VS, Phillis YA (2004) Evaluating strategies for sustainable development: fuzzy logic reasoning and sensitivity analysis. Ecol Econ 48:149-172. https://doi.org/10.1016/J.ECOLECON.2003.08.009

25. Lee YJ, Huang CM (2007) Sustainability index for Taipei. Environ Impact Assess Rev 27:505-521. https://doi.org/10.1016/J.EIAR.2006.12.005

26. Blinc R, Zidanšek A, Šlaus I (2006) Sustainable development after Johannesburg and Iraq: the global situation and the cases of Slovenia and Croatia. Energy 31:2259-2268. https://doi.org/10.1016/J.ENERGY.2006.01.023

27. Spangenberg JH (2002) Institutional sustainability indicators: an analysis of the institutions in Agenda 21 and a draft set of indicators for monitoring their effectivity. Sustain Dev 10:103-115. https://doi.org/10.1002/sd.184

28. Spangenberg JH (2004) Reconciling sustainability and growth: criteria, indicators, policies. Sustain Dev 12:74-86. https://doi.org/10.1002/sd.229

29. UNECOSOC (2002) United Nations Economic and Social Council implementing Agenda 21 — report of the Secretary- General.

30. UNCSD (2001) United Nations Commission on Sustainable Development indicators of sustainable development: framework and methodologies. United Nations.

31. UNDPCSD (1996) United Nations Division for Sustainable Development Department of Policy Co-Ordination and Sustainable Developmentindicators of sustainable development: framework and methodologies.

32. Trigg M, Richter M, Mcmillan S, O'Rourke S, Wong V (2010) Sustainable cities index

33. Zhou N, He G, Williams C, Fridley D (2015) ELITE cities: A low-carbon ecocity evaluation tool for China. Ecol Indic 48:448-456. https://doi.org/10.1016/ J.ECOLIND.2014.09.018

34. Kostevšek A, Klemeš JJ, Varbanov PS, Čuček L, Petek J (2015) Sustainability assessment of the Locally Integrated Energy Sectors for a Slovenian municipality. J Clean Prod 88:83-89. https://doi.org/10.1016/J.JCLEPRO.2014. 04.008 
35. Martínez PCl (2015) Energy and sustainable development in cities: a case study of Bogotá. Energy 92:612-621. https://doi.org/10.1016/J.ENERGY.2015. 02.003

36. Strunz S, Marselle M, Schröter M (2019) Leaving the "sustainability or collapse" narrative behind. Sustain Sci 14:1717-1728. https://doi.org/10. 1007/s11625-019-00673-0

37. Kılkış \$̧ (2016) Sustainable development of energy, water and environment systems index for Southeast European cities. J Clean Prod 130:222-234. https://doi.org/10.1016/J.JCLEPRO.2015.07.121

38. Yang WC, Lee YM, Hu JL (2016) Urban sustainability assessment of Taiwan based on data envelopment analysis. Renew Sustain Energy Rev 61:341353. https://doi.org/10.1016/J.RSER.2016.04.015

39. Liu G (2014) Development of a general sustainability indicator for renewable energy systems: a review. Renew Sustain Energy Rev 31:611-621. https://doi.org/10.1016/J.RSER.2013.12.038

40. Kurka T, Blackwood D (2013) Participatory selection of sustainability criteria and indicators for bioenergy developments. Renew Sustain Energy Rev 24: 92-102. https://doi.org/10.1016/J.RSER.2013.03.062

41. Onat N, Bayar H (2010) The sustainability indicators of power production systems. Renew Sustain Energy Rev 14:3108-3115. https://doi.org/10.1016/J. RSER.2010.07.022

42. Kumar D, Katoch SS (2014) Sustainability indicators for run of the river (RoR) hydropower projects in hydro rich regions of India. Renew Sustain Energy Rev 35:101-108. https://doi.org/10.1016/J.RSER.2014.03.048

43. Tsai WT (2010) Energy sustainability from analysis of sustainable development indicators: a case study in Taiwan. Renew Sustain Energy Rev 14:2131-2138. https://doi.org/10.1016/J.RSER.2010.03.027

44. Mandelli S, Barbieri J, Mattarolo L, Colombo E (2014) Sustainable energy in Africa: a comprehensive data and policies review. Renew Sustain Energy Rev 37:656-686. https://doi.org/10.1016/J.RSER.2014.05.069

45. IEA (2011) World Energy Outlook 2011.

46. IAEA/IEA (2001) Indicators for sustainable energy development-9th session of the Commission on Sustainable Development.

47. Vera IA, Langlois LM, Rogner HH, Jalal Al, Toth FL (2005) Indicators for sustainable energy development: an initiative by the International Atomic Energy Agency. Nat Resour Forum 29:274-283. https://doi.org/10.1111/j. 1477-8947.2005.00140.x

48. Streimikiene D, Ciegis R, Grundey D (2007) Energy indicators for sustainable development in Baltic States. Renew Sustain Energy Rev 11:877-893. https:// doi.org/10.1016/J.RSER.2005.06.004

49. Salimov S (2018) Energy indicators for sustainable development of Azerbaijan Republic- economic dimension. Eur J Sustain Dev 7:236-248

50. Bandura R (2006) A survey of composite indices measuring country performance: 2006 update

51. Patlitzianas KD, Doukas H, Kagiannas AG, Psarras J (2008) Sustainable energy policy indicators: review and recommendations. Renew Energy 33:966-973. https://doi.org/10.1016/j.renene.2007.05.003

52. Jovanović M, Afgan N, Radovanović P, Stevanović V (2009) Sustainable development of the Belgrade energy system. Energy 34:532-539. https:// doi.org/10.1016/J.ENERGY.2008.01.013

53. Mirza B, Szirmai A (2010) Towards a new measurement of energy poverty: a cross-community analysis of rural Pakistan. MERIT Work Pap.

54. Vučićević B, Jovanović M, Afgan N, Turanjanin V (2014) Assessing the sustainability of the energy use of residential buildings in Belgrade through multi-criteria analysis. Energy Build 69:51-61. https://doi.org/10.1016/J. ENBUILD.2013.10.022

55. Iddrisu I, Bhattacharyya SC (2015) Sustainable Energy Development Index: a multi-dimensional indicator for measuring sustainable energy development. Renew Sustain Energy Rev 50:513-530. https://doi.org/10.1016/J.RSER.2015. 05.032

56. Nixon JD, Dey PK, Davies PA (2010) Which is the best solar thermal collection technology for electricity generation in north-west India? Evaluation of options using the analytical hierarchy process. Energy 35: 5230-5240. https://doi.org/10.1016/J.ENERGY.2010.07.042

57. Tsyganok W, Kadenko SV, Andriichuk OV (2012) Significance of expert competence consideration in group decision making using AHP. Int J Prod Res 50:4785-4792. https://doi.org/10.1080/00207543.2012.657967

58. Lee SK, Mogi G, Hui KS (2013) A fuzzy analytic hierarchy process (AHP)/data envelopment analysis (DEA) hybrid model for efficiently allocating energy $R \& D$ resources: In the case of energy technologies against high oil prices.
Renew Sustain Energy Rev 21:347-355. https://doi.org/10.1016/j.rser.2012.12. 067

59. Lee SK, Mogi G, Li Z, Hui KS, Lee SK, Hui KN et al (2011) Measuring the relative efficiency of hydrogen energy technologies for implementing the hydrogen economy: an integrated fuzzy AHP/DEA approach. Int J Hydrogen Energy 36:12655-12663. https://doi.org/10.1016/J.IJHYDENE.2011.06.135

60. Kahraman C, Ertay T, Büyüközkan G (2006) A fuzzy optimization model for QFD planning process using analytic network approach. Eur J Oper Res 171: 390-411. https://doi.org/10.1016/J.EJOR.2004.09.016

61. Charnes A, Cooper WW, Rhodes E (1978) Measuring the efficiency of decision making units. Eur J Oper Res 2:429-444. https://doi.org/10.1016/ 0377-2217(78)90138-8

62. International statistics: Compare countries on just about anything! NationMaster.com https://www.nationmaster.com/

63. https://web.archive.org/web/20150612123716/https://www.cia.gov/library/ publications/ the-world-factbook/fields/2201.html. The World Factbook

64. OECD (2011) The economic significance of natural resources: key points for reformers in Eastern Europe, Caucasus and Central Asia.

65. Patrick SM (2012) Why natural resources are a curse on developing countries and how to fix it - The Atlantic April. https://www.theatlantic.com/ international/archive/2012/04/why-natural-resources-are-a-curse-ondeveloping-countries-and-how-to-fix-it/256508/

66. Frankel JA (2010) The natural resource curse: a survey. HKS Work Pap NoRWP10-005. https://doi.org/10.2139/ssrn.1565588

67. Su F, Wei G, Tao R (2016) China and natural resource curse in developing countries: empirical evidence from a cross-country study. China World Econ Inst World Econ Polit Chinese Acad Soc Sci 24:18-40. https://doi.org/10. 1111/cwe.12142

68. Kona A, Melica G, Rivas Calvete S, Zancanella P, lancu A, Gabrielaitiene I et al (2015) The covenant of mayors in figures and performance indicators: 6-year assessment. https://doi.org/10.2790/774700

69. Keirstead J (2013) Benchmarking urban energy efficiency in the UK. Energy Policy 63:575-587. https://doi.org/10.1016/J.ENPOL.2013.08.063

70. Sovacool BK, Brown MA (2010) Twelve metropolitan carbon footprints: a preliminary comparative global assessment. Energy Policy 38:4856-4869. https://doi.org/10.1016/J.ENPOL.2009.10.001

71. Bi J, Zhang R, Wang H, Liu M, Wu Y (2011) The benchmarks of carbon emissions and policy implications for China's cities: case of Nanjing. Energy Policy 39:4785-4794. https://doi.org/10.1016/j.enpol.2011.06.045

72. Dong Y, Xia B, Chen W (2014) Carbon footprint of urban areas: an analysis based on emission sources account model. Environ Sci Policy 44:181-189. https://doi.org/10.1016/j.envsci.2014.07.013

73. Zhang $Y$, Linlin X, Weining X (2014) Analyzing spatial patterns of urban carbon metabolism: a case study in Beijing, China. Landsc Urban Plan 130: 184-200. https://doi.org/10.1016/j.landurbplan.2014.05.006

74. Khanna N, Fridley D, Hong L (2014) China's pilot low-carbon city initiative: a comparative assessment of national goals and local plans. Sustain Cities Soc 12:110-121. https://doi.org/10.1016/J.SCS.2014.03.005

75. Kramers A, Wangel J, Johansson S, Höjer M, Finnveden G, Brandt N (2013) Towards a comprehensive system of methodological considerations for cities' climate targets. Energy Policy 62:1276-1287. https://doi.org/10.1016/J. ENPOL.2013.06.093

76. Alonso A, Monzón A, Cascajo R (2015) Comparative analysis of passenger transport sustainability in European cities. Ecol Indic 48:578-592. https://doi. org/10.1016/J.ECOLIND.2014.09.022

77. Debnath AK, Chin HC, Haque MM, Yuen B (2014) A methodological framework for benchmarking smart transport cities. Cities 37:47-56. https:// doi.org/10.1016/J.CITIES.2013.11.004

78. Miranda H De F, Rodrigues da Silva AN (2012) Benchmarking sustainable urban mobility: the case of Curitiba, Brazil. Transp Policy 21:141-151. https:// doi.org/10.1016/J.TRANPOL.2012.03.009

79. Zaman AU, Lehmann S (2013) The zero waste index: a performance measurement tool for waste management systems in a "zero waste city". J Clean Prod 50:123-132. https://doi.org/10.1016/J.JCLEPRO.2012.11.041

80. Karagiannidis A, Xirogiannopoulou A, Perkoulidis G, Moussiopoulos N (2004) Assessing the collection of urban solid wastes: a step towards municipality benchmarking. Water, Air, Soil Pollut Focus 4:397-409. https://doi.org/10. 1023/B:WAFO.0000044813.50757.a7

81. Wilson DC, Rodic L, Cowing MJ, Velis CA, Whiteman AD, Scheinberg A et al (2015) "Wasteaware" benchmark indicators for integrated sustainable waste 
management in cities. Waste Manag 35:329-342. https://doi.org/10.1016/J. WASMAN.2014.10.006

82. Wu L, Mao XQ, Zeng A (2015) Carbon footprint accounting in support of city water supply infrastructure siting decision making: a case study in Ningbo, China. J Clean Prod 103:737-746. https://doi.org/10.1016/J.JCLEPRO. 2015.01.060

83. Venkatesh G, Chan A, Brattebø H (2014) Understanding the water-energycarbon nexus in urban water utilities: comparison of four city case studies and the relevant influencing factors. Energy 75:153-166. https://doi.org/10 1016/J.ENERGY.2014.06.111

84. Arribas-Bel D, Kourtit K, Nijkamp P (2013) Benchmarking of world cities through self-organizing maps. Cities 31:248-257. https://doi.org/10.1016/J. CITIES.2012.06.019

85. Afgan NH, Carvalho MG, Hovanov NV (2000) Energy system assessment with sustainability indicators. Energy Policy 28:603-612. https://doi.org/10.1016/ S0301-4215(00)00045-8

\section{Publisher's Note}

Springer Nature remains neutral with regard to jurisdictional claims in published maps and institutional affiliations.

Ready to submit your research? Choose BMC and benefit from:

- fast, convenient online submission

- thorough peer review by experienced researchers in your field

- rapid publication on acceptance

- support for research data, including large and complex data types

- gold Open Access which fosters wider collaboration and increased citations

- maximum visibility for your research: over $100 \mathrm{M}$ website views per year

At BMC, research is always in progress.

Learn more biomedcentral.com/submissions 